\title{
Entraînement des matériaux par charriage
}

\author{
PAR J. ROTTNER \\ INGÉNIEUR A LA SOGREAH, GRENOBIE .
}

English text p. 301

\begin{abstract}
Le débit solide d'un cours d'eau naturel est soumis, en plus des paramètres généraux de l'écoulement tels que la pente, le débit, etc., aux conditions locales, variables alans le temps et dans l'espace, et, de ce fait, insaisissablesL'élaboration d'une formule doit done s'appuyjer en premier lieu sur des résultats de mesures effectuées en laboratoire, dans un canal expérimental. La publication de J.W. Johnson : « Laboratory investigations on bed-load transportation and bed-roughness $»$ a permis de réunir environ 2500 résultats de mesures et de constituer ainsi une base de recherche, féconde par son abondance, mais alssi précaire par sa diversité.
\end{abstract}

L'étude du débit solide dans les canaux expérimentaux et, plus généralement, dans les cours d'eau naturels, a donné naissance à de nombreuses formules. Citons, parmi les hydrauliciens ayant examiné ce problème, les noms de MeyerPeter, Einstein, Schoklitsch, Kalinske; Wilhelm, Du Boys, Rindlaub, Kramer, etc. Ces auteurs ne considèrent, à quelques exceptions près, que le transport solide par charriage en ignorant les particules pouvant être transportées en suspension dans le liquide. Notre étude se limitera aussi à ce premier point de vue.

Dans une première partie, nous examinerons la variation du débit solide, en fonction d'autres grandeurs, précisées par la suite. Puis, nous essaierons de déterminer la vitesse du liquide transporteur en fonction de ces mêmes grandeurs. En dernier lieu, nous tracerons un abaque permettant de trouver le débit solide et la vitesse du liquide à partir de la connaissance des autres paramètres.

\begin{abstract}
Une formule est proposée, évaluant le débit solide par charriage en fonction des parametres de l'écoulement. Il y correspond un abaque, d'exploitation relativement aisée. Dans une deaxième partie, la variation de la vitesse moyenne de l'eau, en présence de matériaux. charriés, est examinée et le résultat en est porté sur un abaque plus complet que le précédent, permettant de déterminer le débit solide et la vitesse moyenne de l'eau a partir de la. connaissance de la pente, de la profondeur de l'écoulement et de la dimension du matériau.
\end{abstract}

Les auteurs précédemment cités utilisent un certain nombre de paramètres tels que :

$h$ : profondeur d'eau;

$i$ : la pente;

$v$ : la vitesse moyenne de l'eau;

$\tau=\gamma h i:$ la force tractrice;

$\mathrm{U}_{*}=\sqrt{\tau / 0}:$ la vitesse de frottement;

$d$ : une dimension du grain;

Q: le débit liquide;

$W$ : la largeur;

$\rho^{\prime}$ : la masse spécifique du grain.

etc...

Il semble acquis, dès le premier examen, que l'on ne peut plus songer à calculer le débit solide d'un cours d'eau que dans une section où toutes les grandeurs sont bien définies. Le cas le plus simple, celui auquel les auteurs se rapportent presque toujours, est celui d'une section 
rectangulaire, aux largeur et profondeur bien déterminées, où l'écoulement est uniforme. Dès que l'on s'écarte de ces conditions, la définition de plusieurs grandeurs, telles que la pente, les dimensions de la section, devient arbitraire et, par là, tout calcul d'une valeur aléatoire. Dans ce qui suit, nous nous tiendrons strictement à cet état idéal.

On sait que, pour une largeur grande par rapport à la profondeur, l'écoulement ne fait plus intervenir qu'un seule dimension, la cote du point considéré. Autrement dit, l'effet des parois est négligeable ou, du moins, se limite au voisinage immédiat de ces dernières. Dès lors, le débit solide est constant sur toute la largeur de l'écoulement et ne dépend plus de cette dimension. Nous nous placerons encore dans ces conditions idéales. On pourra toujours, par une méthode appropriée à trouver, tenir compte, par la suite, de cet effet.

Le débit solide par unitề de largeur est déterminé lorsque l'on se donne :

$h$, la profondeur,

$i$, la pente,

$d$, la dimension des grains et leur densité (el des facteurs de forme s'il y a lieu),

les constantes physiques o, $g$, y la viscosité.

Si le matériau n'est pas uniforme, $d$ reprèsente une dimension moyenne. On verra par la suite que le calcul de nos groupements de paramètres avec la valeur de $d$ indiquée par l'expérimentateur fournit un ensemble de points où l'on ne distingue pas ceux correspondant à un $d$ uniforme des autres. Nous pensons donc qu'il existe une définition du diamètre moyen du grain permettant de calculer le débit solide avec une approximation qui est en proportion avec la précision habituelle de ce genre de calcul.

La connaissance des paramètres énumérés plus haut, détermine également la vitesse moyenne. ou, mieux, le débit de liquide par unité de largeur. Ainsi :

$$
\mathrm{Q}=f_{1}\left(h, i, d, e^{\prime}, e, g, v\right)
$$

el :

$$
\mathrm{G}(\text { débit solide })=f_{2}\left(h, i, d, \rho^{\prime}, p, g, v\right)
$$

Si nous éliminons $i$ entre ces deux relations formelles, il vient:

$$
\mathrm{G}=f\left(\mathrm{Q}, h, d, \hat{e}^{\prime} \bullet, g, \nu\right)
$$

L'analyse dimensionnelle, appliquée à ces grandeurs, conduit à une relation entre les groupements suivants :

$$
\frac{\mathrm{G}}{\rho \sqrt{g h^{3}}}, \frac{\mathrm{Q}}{\rho \sqrt{g h^{3}}}, \frac{h}{d}, \frac{\varphi^{\prime}}{\rho}, \frac{\nu}{\sqrt{g h^{3}}}
$$

Le deuxième n'est autre que le nombre de Froude du liquide. Le premier, de formation identique, peut être considéré comme le nombre de Froude du grain.

Dans la plupart des cas, la turbulence est franchement développée, de sorte que le dernier groupement n'intervient plus. On sait qu'il en est ainsi pour l'écoulement d'eau claire dans les conduites circulaires. Il semble donc justifié d'admettre ici la même hypothèse.

il reste ainsi :

$$
\frac{\mathrm{G}}{\rho \sqrt{g h^{3}}}, \frac{\mathrm{Q}}{\rho \sqrt{g h^{3}}}, \frac{v}{\sqrt{g h}}, \frac{h}{d}, \frac{\rho^{\prime}}{\ominus}
$$

$G / \rho \sqrt{g h^{3}}$ peut être remplacé par $G / \rho^{\prime} \sqrt{g h^{3}}$ par multiplication du premier par $\rho / \rho^{\prime}$. Ce deuxième groupement se rapporte au débit solide en volume.

Par ailleurs, l'expérience et les formules des divers auteurs montrent que $q^{\prime} / \rho$ intervient intimement lié aux autres groupements. Si l'on examine, sur un schéma très simple, les forces agissant sur un grain, on constate que la masse spécifique du matériau intervient par $g\left(q^{\prime}-p\right) / \mathrm{s}$ (rapport du poids apparent à la force hydrodynamique). Nous avons donc admis que $\% / \rho$ n'intervenait que sous cette forme, et avons ainsi été conduits aux groupements :

$$
\begin{aligned}
& \frac{G}{q^{\prime} \sqrt{g h^{3}\left(q^{\prime}-p\right) / q}}, \frac{Q}{? \sqrt{g h^{2}\left(q^{\prime}-q\right) / p}}, \\
& \frac{V}{\sqrt{g h\left(\rho^{\prime}-\rho\right) / \rho}}, \frac{h}{d}
\end{aligned}
$$

Par la vérification de ces hypothèses, nous disposions des résultats publiés par J.W. Johnson dans « Laboratory investigations on bed-load transportation and bed roughness $\gg$. Ces données se rapportent à des mesures effectuées par Gilbert, C.H. MacDougall, S.D. Chyn, Jorissen, U.S.W.E.S., T.Y. Liu, C.H. Yen, M.P. O'Brien, H.C. Casey, Pang-Yung Ho.

Les matériaux utilisés par ces auteurs avaient pour caractéristiques celles figurant au tableau I ci-contre.

Il nous a été ainsi possible d'assembler plus de 2500 résultats de mesure, que nous avons classés par valeurs de $h / d$ croissantes. Ils ont été groupés en 46 «pages», contenant chacune une cinquantaine de points. Les calculs ont été elfectués sur ordinateur IBM 650. (Voir tableau page 291.)

Pour chaque page - sauf pour les deux dernières où les points étaient trop groupés — nous avons porté les points dans le système d'axes :

$$
y=\frac{\mathrm{V}}{\sqrt{h\left(\rho^{\prime}-\varphi\right) / \rho}} \quad x=\left[\frac{\mathrm{G}}{\rho^{\prime} \sqrt{h^{3}\left(\rho^{\prime}-\rho\right) / \rho}}\right]^{1 / 3}
$$




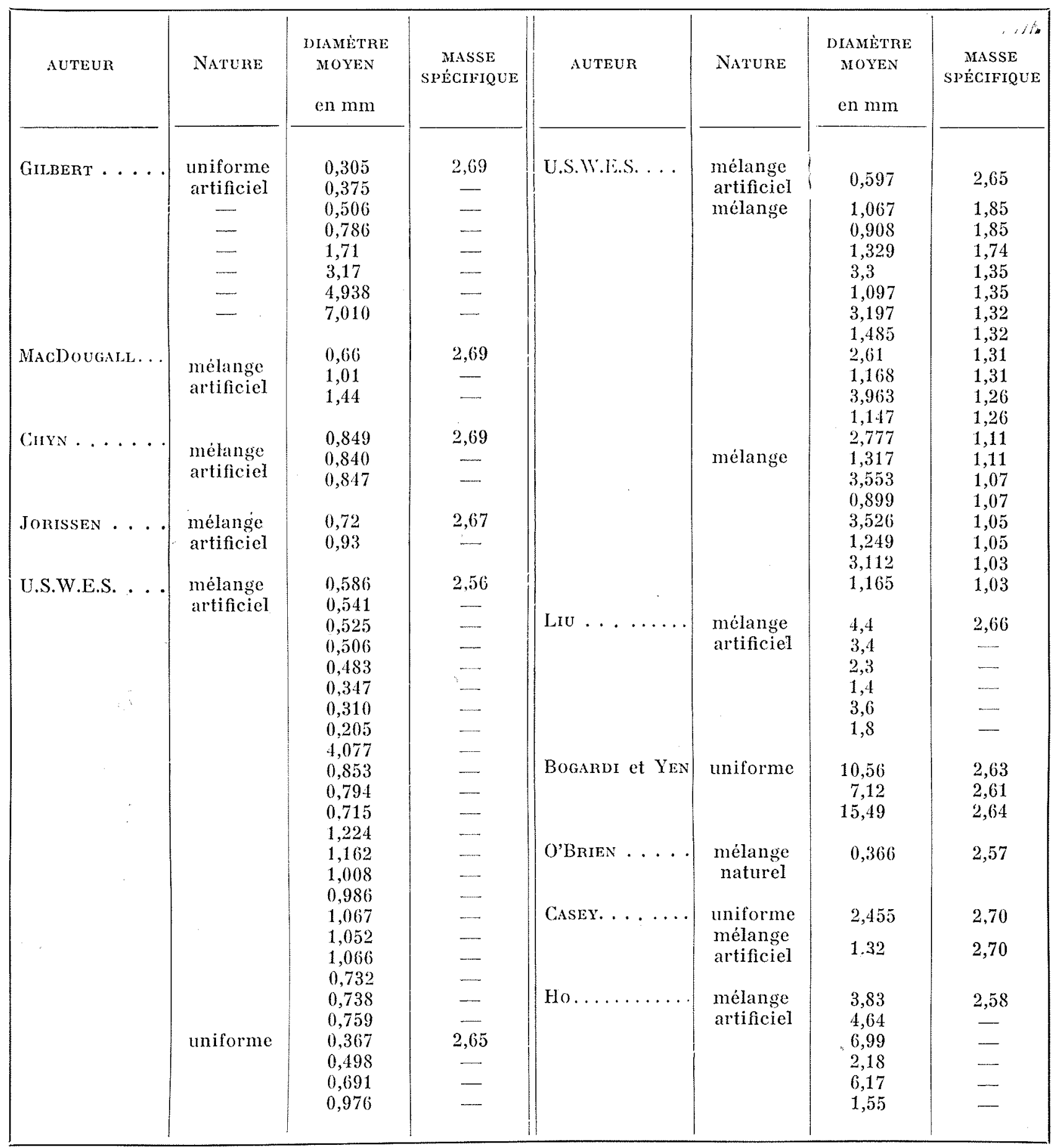

où $G$ est exprimé en grammes par seconde par centimètre de largeur,

$V$ en centimètres par seconde,

$h$ en centimètres.

Les résultats sont portés sur le groupe de figures $\mathbf{n}^{\circ} 1$.
Les points s'ordonnent de façon satisfaisante autour de droites $x=a y-b$. Pour certaines pages cependant, le début de la courbe - pour les petites valeurs de $y$ - semble vouloir se raccorder perpendiculairement à l'axe des $y$. Ceci n'a pas été assez net, ni assez fréquent, pour que nous ayons pu conclure de façon nette. Une remarque analogue peut se situer à l'autre extrémité de la droite. 


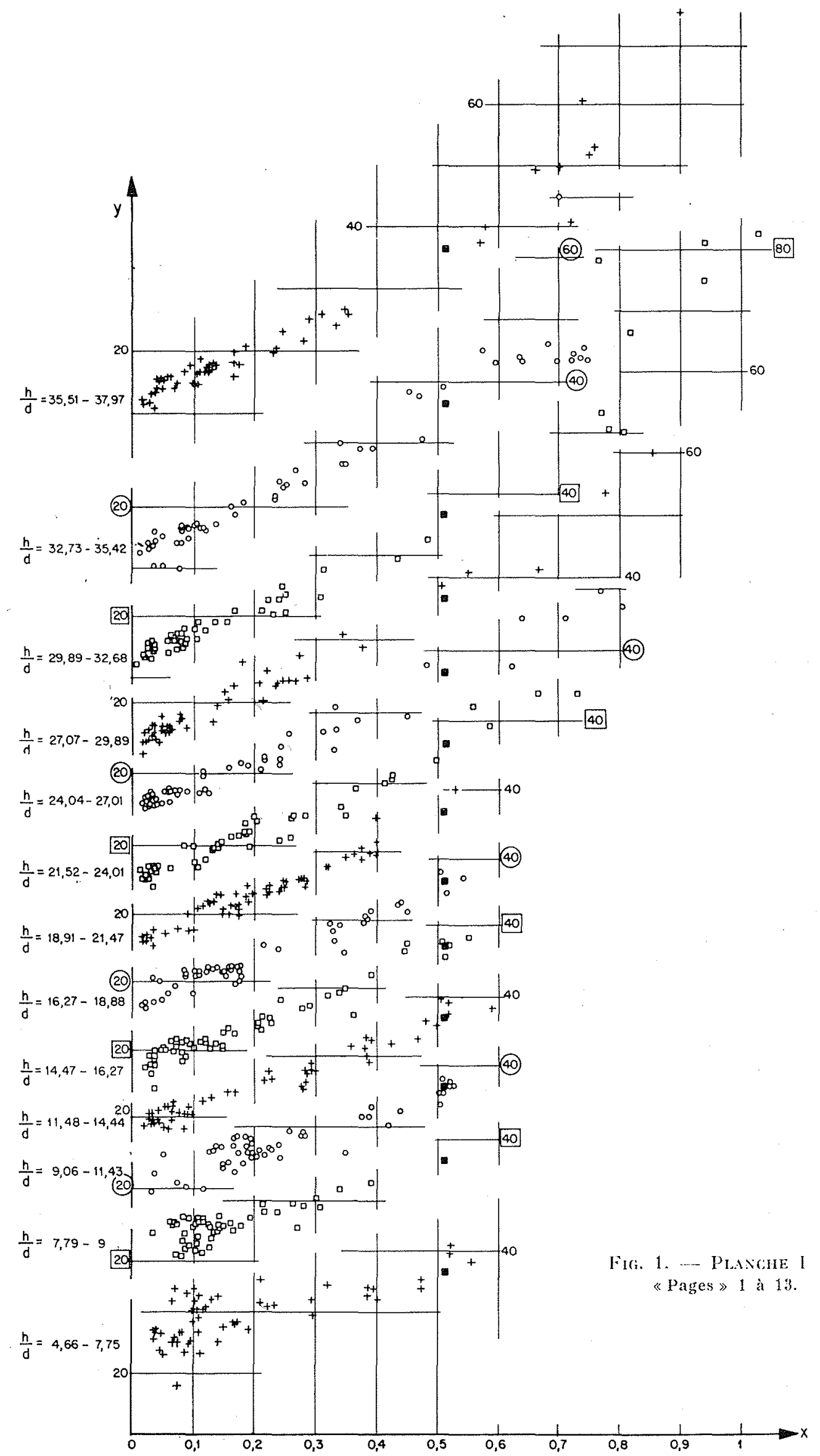



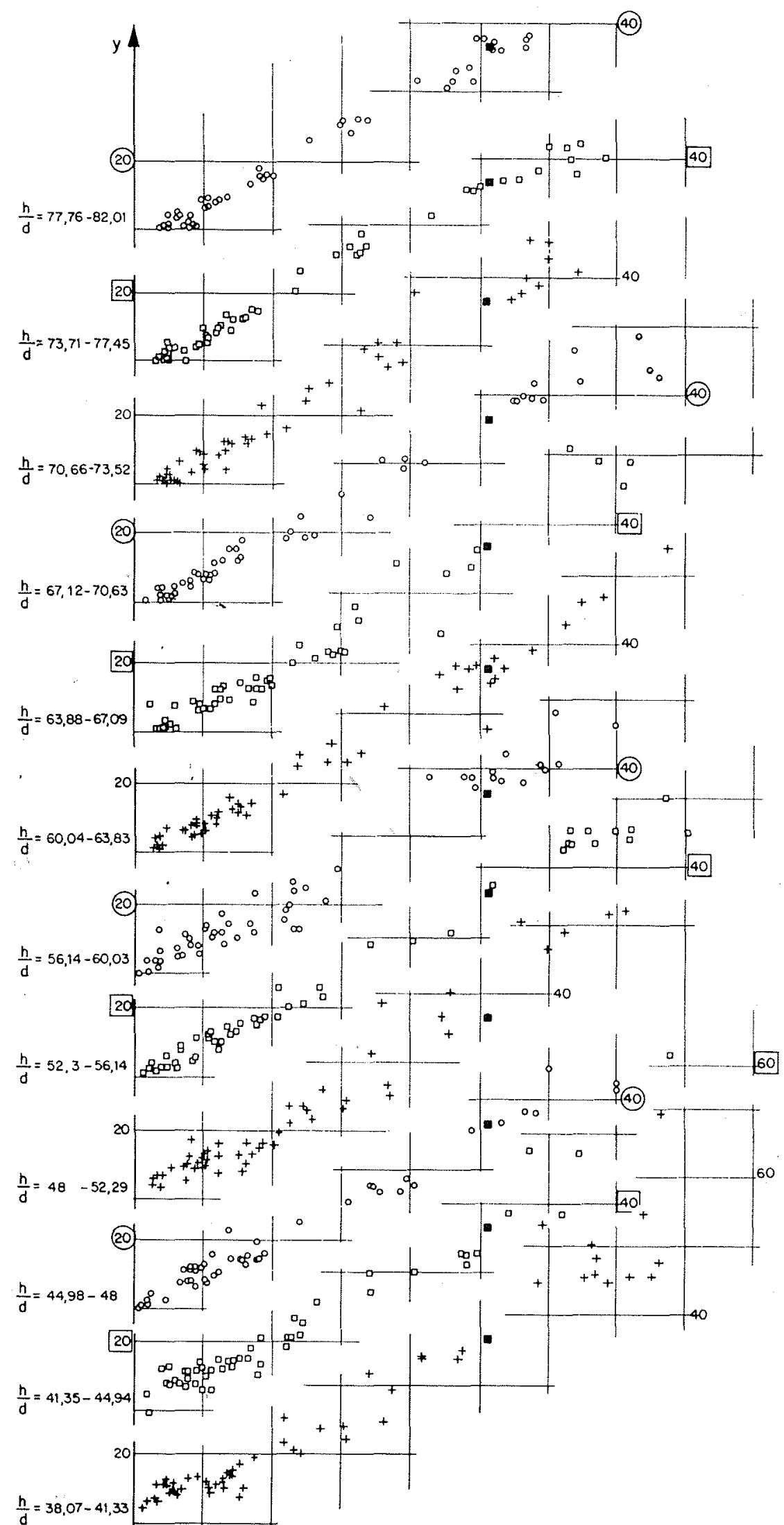

Fig. 1. - Planche II «Pages» 14 a 25. 

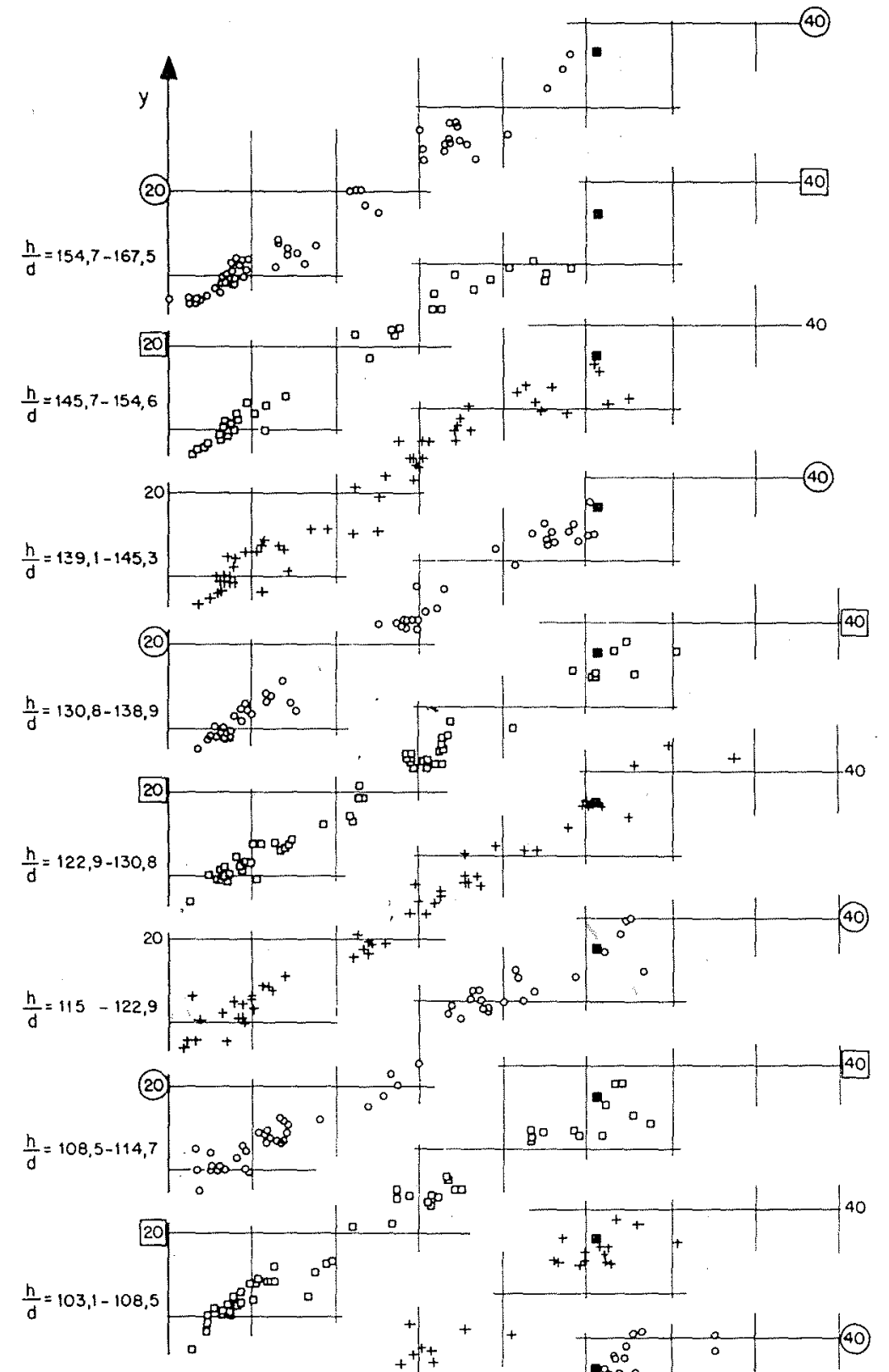

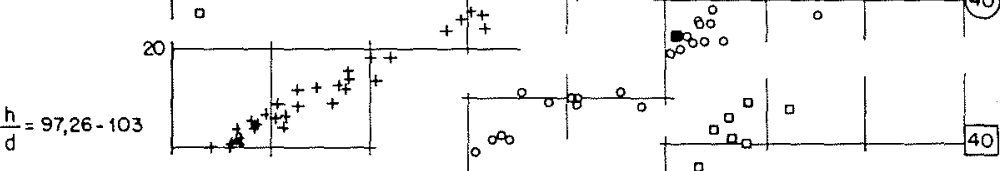
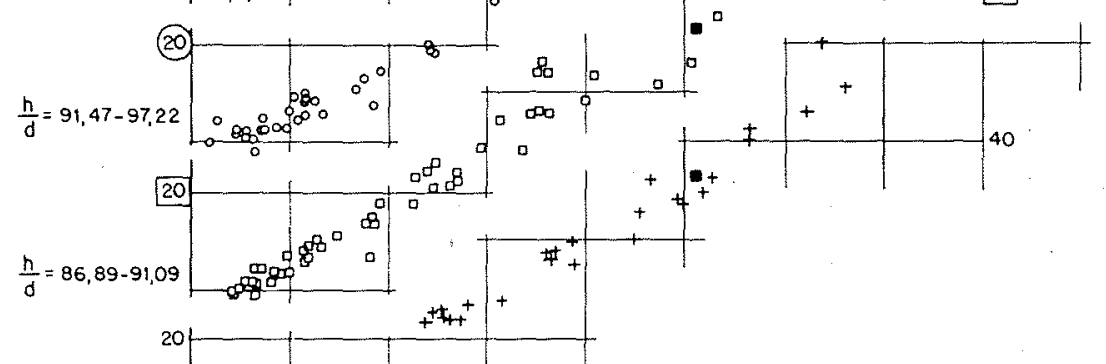

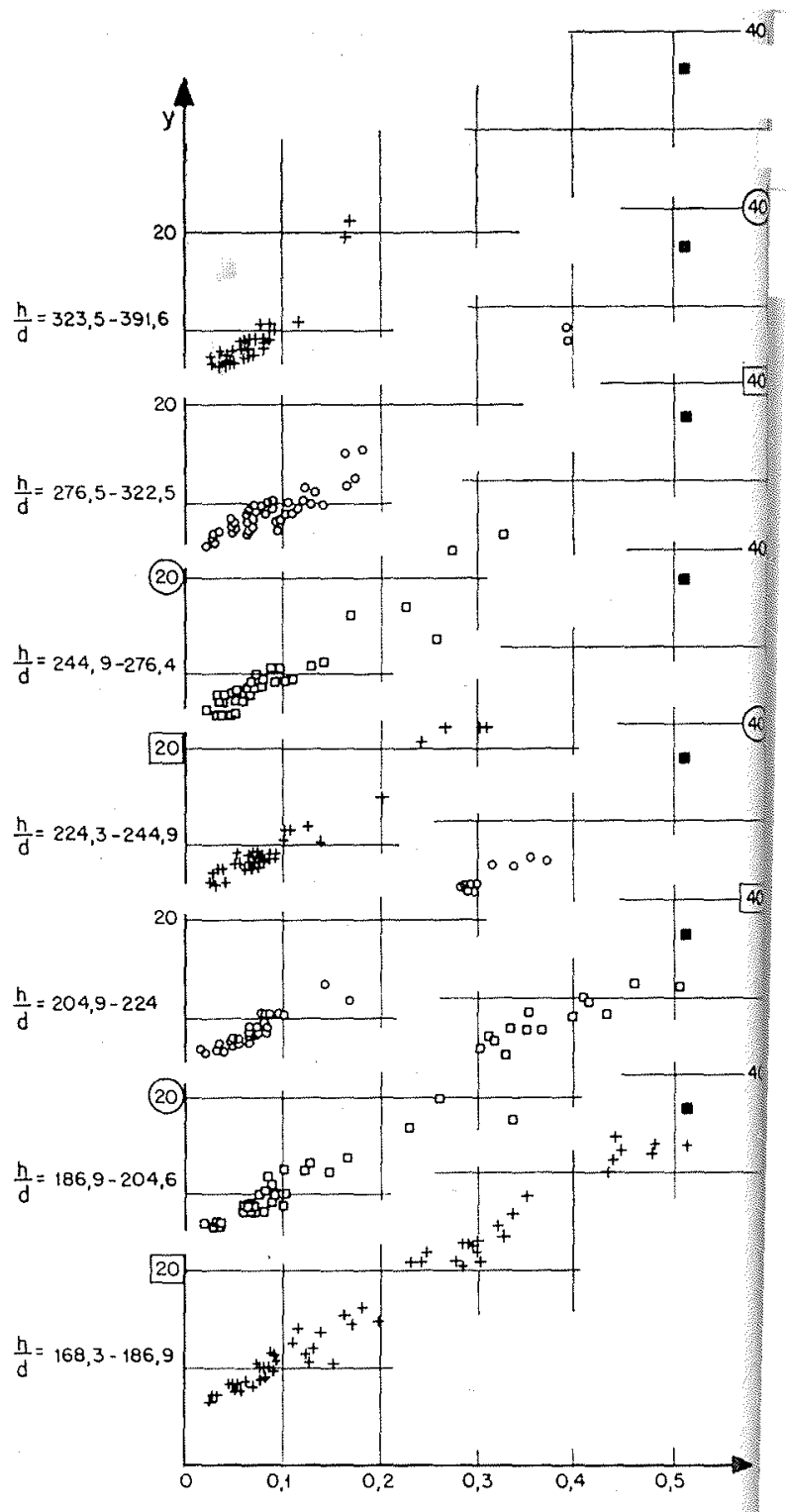

Fig. 1 - Planchf. IV «Pages» 38 a 44.

Fig. 1. - Plasche III «Pages» 26 à 37.

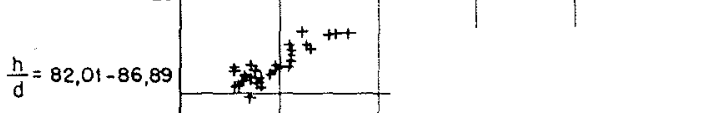




\begin{tabular}{|c|c|c|}
\hline Page & $h / d$ & Valeur moyenne de $h / d$ \\
\hline 1 & $4,66 \ldots$ & 6,71 \\
\hline 2 & $7,79-9$ & 8,38 \\
\hline 3 & $9,06-11,43$ & 10,1 \\
\hline 4 & $11,48-14,44$ & 12,9 \\
\hline 5 & $14,47 \ldots \quad 16,27$ & 15,3 \\
\hline 6 & $16,27-18,88$ & 17,3 \\
\hline 7 & $18,91-21,47$ & 20,1 \\
\hline 8 & $21,52-24,01$ & 22,6 \\
\hline 9 & $24,04-27,01$ & 25.6 \\
\hline 10 & $27,07-29,89$ & 28,3 \\
\hline 11 & $29,89-32,58$ & 31,3 \\
\hline 12 & $32,73 \ldots-35,42$ & 34 \\
\hline 13 & $35,51-37,97$ & 36,7 \\
\hline 14 & $38,07-41,33$ & 39,7 \\
\hline 15 & $41,35-44,94$ & 43 \\
\hline 16 & $44,98 \ldots 48$ & 46,6 \\
\hline 17 & $48-52,29$ & 49,8 \\
\hline 18 & $52,3 \quad \ldots \quad 56,14$ & 54,2 \\
\hline 19 & $56,14-60,03$ & 58,1 \\
\hline 20 & $60,04-63,83$ & 61,5 \\
\hline 21 & $63,88-67,09$. & 65,3 \\
\hline 22 & $67,12-70,63$ & 69 \\
\hline 23 & $70,66-73.52$ & 71,9 \\
\hline 24 & $73,71-77,45$ & 75,7 \\
\hline 25 & $77,76-82,01$ & 79,6 \\
\hline 26 & $82,01-86,89$ & 84,5 \\
\hline 27 & $86,89-91,09$ & 89,1 \\
\hline 28 & $91,47-97,22$ & 93,7 \\
\hline 29 & $97,26-103$ & 99,7 \\
\hline 30 & $103,1-108,5$ & 105 \\
\hline 31 & $108,5-114,7$ & 112 \\
\hline 32 & $11 \tilde{5}-122,9$ & 119 \\
\hline 33 & $122,9-130,8$ & 126 \\
\hline 34 & $130,8-138,9$ & 134 \\
\hline 35 & $139,1-145,3$ & 142 \\
\hline 36 & $145,7-154,6$ & 151 \\
\hline 37 & $154,7-167,5$ & 161 \\
\hline 38 & $168,3-186,9$ & 178 \\
\hline 30 & $186,9-204,6$ & 193 \\
\hline 40 & $204,9--224$ & 215 \\
\hline 41 & $-244,9$ & 233 \\
\hline 42 & $244,9-276,4$ & 262 \\
\hline 43 & $276,5-322,5$ & 298 \\
\hline 44 & $323,5-391,6$ & 350 \\
\hline 45 & $392-862,8$ & 4.72 \\
\hline 46 & $863,7-896,6$ & 876 \\
\hline
\end{tabular}

Nous expliquons la dispersion importante de la page 1 par l'importance des variations de $h / d$ (de 4,66 à 7,75).

Afin d'avoir un élément de comparaison pour juger de la dispersion des points autour des droiles, nous avons, pour les pages $12,24,30$ et 35 , porté ces mèmes points sur un graphique dont les coordonnées sont les groupements de la formule de Meyer-Peter :

$$
\begin{aligned}
\gamma_{x}\left(\mathrm{Q}_{s} / \mathrm{Q}\right)\left(k_{s} / k_{r}\right)^{3 / 2} h i=0,047 & \gamma^{\prime \prime}{ }_{s} d \\
& +0,25\left(\gamma_{x} / g\right)^{1 / 3} g_{s}^{\prime \prime 2 / 3}
\end{aligned}
$$

ò̀ :

$$
\begin{aligned}
\gamma_{w}= & g \rho, \\
\gamma^{\prime \prime} \mathrm{s}= & g\left(\rho^{\prime}-\rho-\rho\right), \\
g^{\prime \prime}= & \text { débit solide, par unité de largeur, } \\
& \text { pesé sous l'eau. }
\end{aligned}
$$

Comme nous n'avions nous-même effectué aucune correction pour tenir compte de l'influence des parois latérales, de la présence éventuelle de dunes, de la variation de $h / d$ pour une même page, nous avons ramené la formule de MeyerPeter à la forme plus simple:

$$
h i / d=\mathrm{A} \gamma^{\prime \prime}{ }_{s}+\mathrm{B}\left(g^{\prime \prime}{ }_{s} / h\right)^{2 / 3}(h / d)
$$

ou :

$\frac{h i}{d\left(\rho^{\prime}-\rho\right) / \rho}=\mathrm{A}+\mathrm{B}\left[\frac{\mathrm{G}}{\rho^{\prime} \sqrt{\left[\left(\rho^{\prime}-\rho\right) / \rho\right] h^{3}}}\right]^{2 / 3} h / d$

$h / d$ étant, de plus, supposé constant pour chaque page, il reste les groupements :

$$
\frac{h i}{d\left(\varphi^{\prime}-\rho\right) / \rho} \text { et }\left[\frac{\mathrm{G}}{\rho^{\prime} \sqrt{\left[\left(\rho^{\prime}-\rho\right) / \rho\right] h^{3}}}\right]^{1 / 3}
$$

L'exposant $1 / 3$, celui de nos graphiques, a été choisi pour rendre les dispersions comparables (voir le groupe de figures $n^{\circ} 2$ ).

Ainsi que nous l'avons déjà indiqué, les courbes obtenues peurent être représentées, assez bien nous semble-t-il, par des droites. Les quelques divergences relevées aux deux extrémités des droites ne nous ont pas paru suffisantes pour que nous rejetions cette représentation. Quoi qu'il en soit, il sera toujour's possible, par des mesures à faire, de préciser ces points et d'adopter, si besoin était, une forme plus complexe qu'une simple droite. On peut noter, à ce sujet, que la formule de Meyer-Peter se ramène, si on

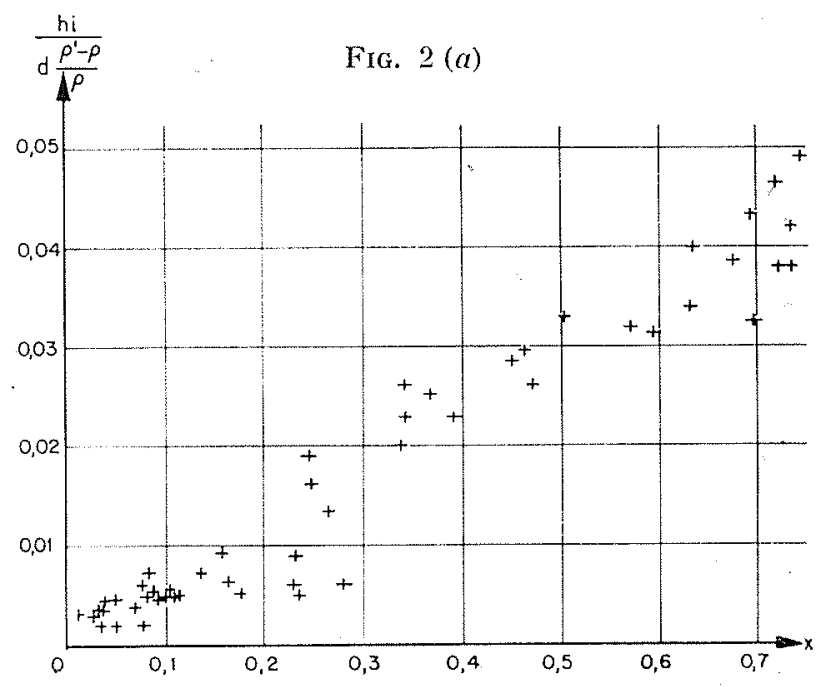




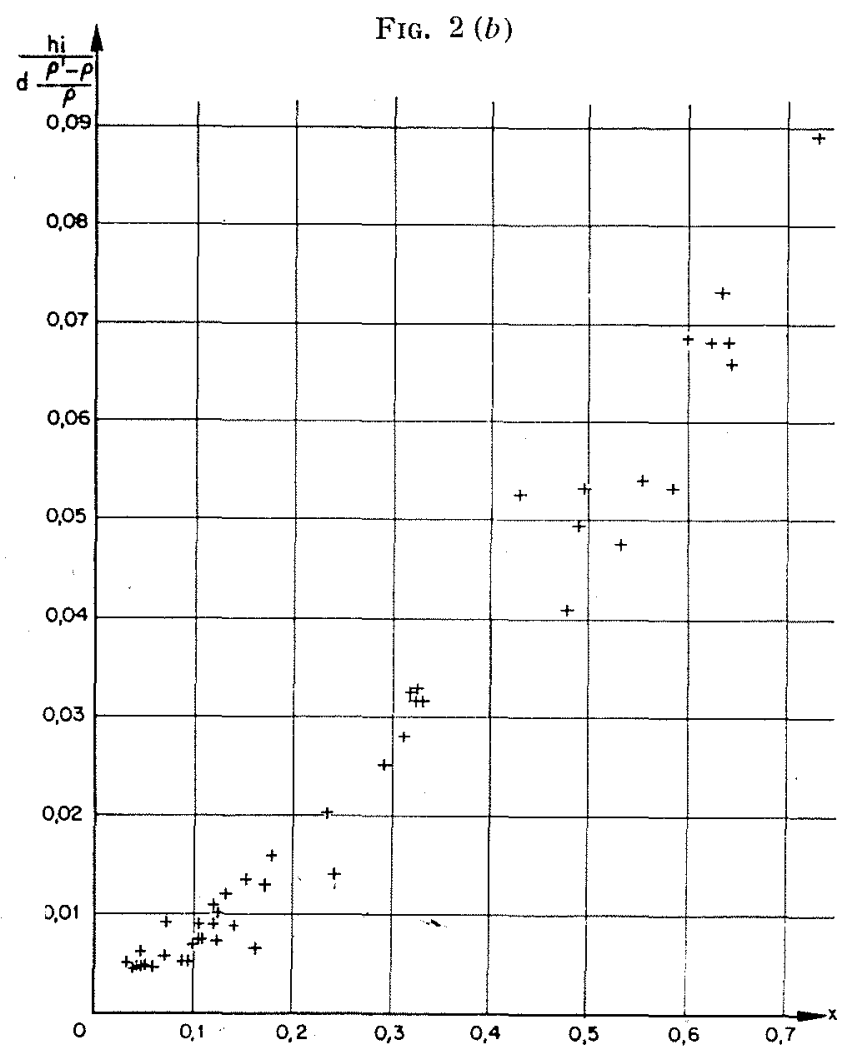

la transforme par la relation de Manning :

$$
\mathrm{V}=(h / d)^{1 / 6} \sqrt{h i}
$$

à une relation linéaire entre $x^{2}$ et $y^{2}$. Plusieurs auteurs russes ont d'ailleurs proposé des formules utilisant les mêmes groupements de paramètres. Citons, entre autre, celle de I.L. Lévy :

$\mathrm{G} / \sqrt{h^{3}}=(u / \sqrt{g d})^{3}(h / d)^{3 / 2}$

$$
\left[1--a(\sqrt{g d} / u)(h / d)^{0,16}\right](u / \sqrt{h})
$$

qui peut s'écrire :

$$
\mathrm{G} / \bar{V}^{3}=(u / \sqrt{h})^{3}\left[(u / \sqrt{h})-a(h / d)^{-0.34}\right]
$$

soit, avec nos variables $x$ et $y$ :

$$
x^{3}=y^{3}[y-a(h / d)-0,34]
$$

Nous avons calculé, par la méthode des moin-

\begin{tabular}{|c|c|c|c|c|}
\hline Page & $h / d$ & $100 a$ & $10 \mathrm{~b}$ & $b / a$ \\
\hline 1 & 6,71 & 2,39 & $\check{5}, 33$ & 22,3 \\
\hline 2 & 8,38 & 2,28 & 4,47 & 19,6 \\
\hline 3 & 10,1 & 3,01 & 5,84 & 19,4 \\
\hline 4 & 12,9 & 2,71 & 4,76 & 17,6 \\
\hline 5 & 15,3 & 2,44 & 3,98 & 16,3 \\
\hline 6 & 17,3 & 2,25 & 3,29 & 14,6 \\
\hline 7 & 20,1 & 2,47 & 3,65 & 14,8 \\
\hline 8 & 22,6 & 2,3 & 3,16 & 13,7 \\
\hline 9 & 25,6 & 2.27 & 3,11 & 13,7 \\
\hline 10 & 28,3 & 1,88 & 2,23 & 11,9 \\
\hline 11 & 31,3 & 2,43 & 2,54 & 10,5 \\
\hline 12 & 34 & 2,08 & 2,41 & 11,6 \\
\hline 13 & 36,7 & 2,07 & 2,28 & 11 \\
\hline 14 & 39,7 & 1,79 & 1,74 & 9,69 \\
\hline 15 & 43 & 2,07 & 2,15 & 30,4 \\
\hline 16 & 46,6 & 2,02 & 2,04 & 10,1 \\
\hline 17 & 49,8 & 1,57 & 1,26 & 8,01 \\
\hline 18 & 54,2 & 1,9 & 1,7 & 8,97 \\
\hline 19 & 58,1 & 1,75 & 1,55 & 8,82 \\
\hline 20 & 61,5 & 1,78 & 1,53 & 8,49 \\
\hline 21 & 65,3 & 1,74 & 1,3 & 7,48 \\
\hline 22 & 69 & 1,8 & 1,45 & 8,03 \\
\hline 23 & 71,9 & 1,71 & 1,29 & 7,52 \\
\hline 24 & 75,7 & 1,85 & 1,51 & 8,15 \\
\hline 25 & 79,6 & 1,77 & 1,23 & 6,95 \\
\hline 26 & 84,5 . & 1,76 & 1,3 & 7,39 \\
\hline 27 & 89,1 & 1,71 & 1,19 & 6,96 \\
\hline 28 & 93,7 & 1,86 & 1,36 & 7,3 \\
\hline 29 & 99,7 & 1,88 & 1,39 & 7,37 \\
\hline 30 & 105 & 1,88 & 1,31 & 7 \\
\hline 31 & 112 & 1,67 & 1,11 & 6,66 \\
\hline 32 & 119 & 1,76 & 1,09 & 6,2 \\
\hline 33 & 126 & 1,76 & 1,07 & 6,08 \\
\hline 34 & 134 & 1,64 & 0,944 & 5,77 \\
\hline 35 & 142 & 1,6 & 0,824 & 5,14 \\
\hline 36 & 151 & 1,78 & 1,02 & 5,75 \\
\hline 37 & 161 & 1,59 & 0,769 & 4,83 \\
\hline 38 & 178 & 1,66 & 0,816 & 4,92 \\
\hline 39 & 193 & 1,52 & 0,615 & 4,05 \\
\hline 40 & 215 & 1,56 & 0,682 & 4,38 \\
\hline 41 & 233 & 1,63 & 0,693 & 4,26 \\
\hline 42 & 262 & 1,52 & 0,592 & 3,9 \\
\hline 43 & 298 & 1,78 & 0,793 & 4,46 \\
\hline 44 & 350 & 1,22 & 0,373 & 3,06 \\
\hline 45 & 472 & 1,52 & 0,542 & 3,56 \\
\hline 46 & 870 & 1,62 & 0,568 & 3,51 \\
\hline
\end{tabular}
dres carrés, les meilleures valeurs des coefficients $a$ et $b$ de $x=a y-b$ et nous en avons déduit $b / a$ caractérisant le début d'entraînement : 


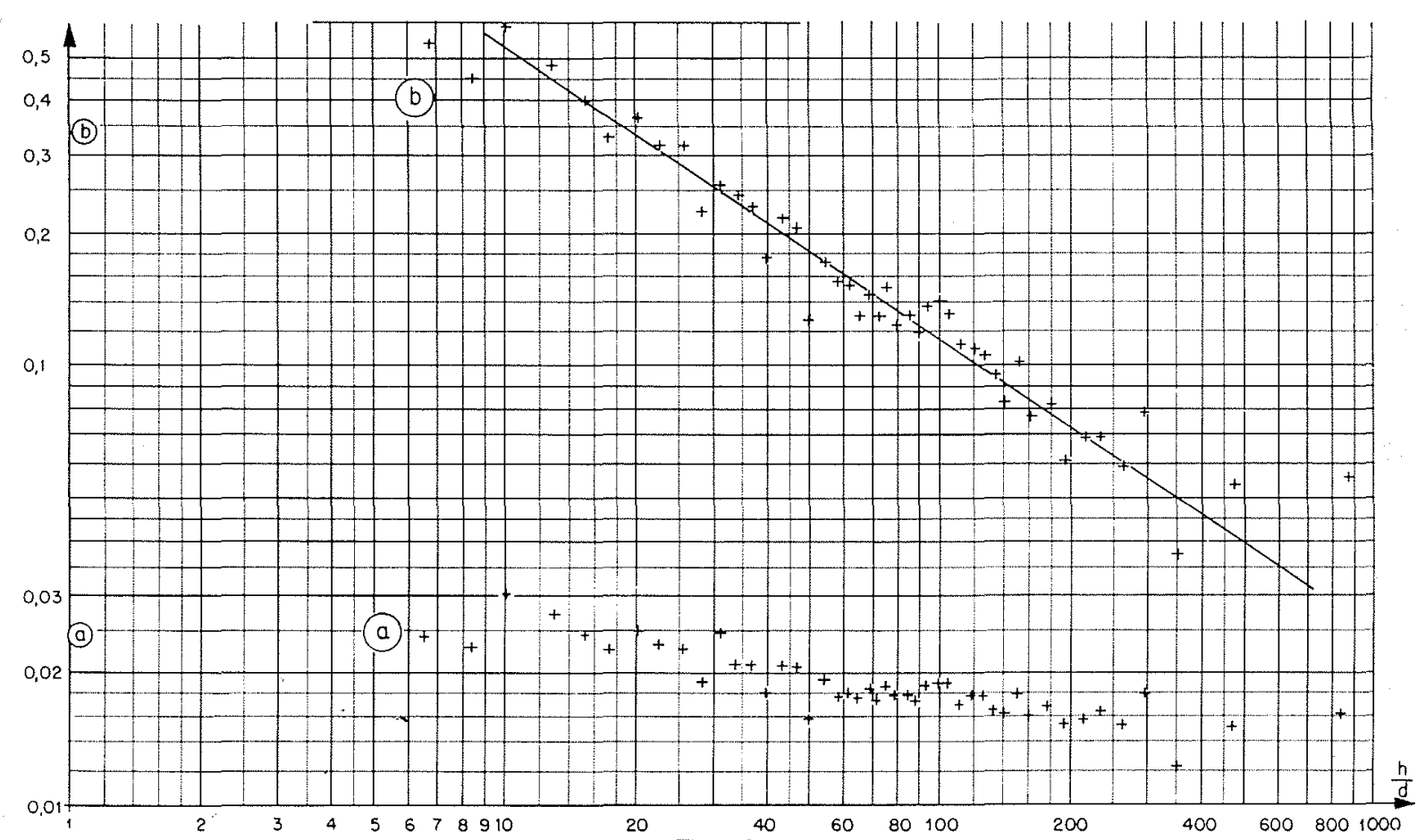

Fig. 3

En coordonnées logarithmiques, les points représentant $b$ se groupent bien autour de la droite $b=2,45(d / h)^{2 / 3}$ : il n'en est pas de même pour $a$, ni pour $b / a$ (voir les figures 3 et 5 ). Si cependant nous portons en coordonnées naturelles $a$ en fonction de $b$ (voir fig. 4), nous voyons les points se grouper autour de la droite :

$$
a=0,02741 b \div 0,01405
$$

d'où nous tirons :

$$
a=0,06715(d / h)^{2 / 3}+0,01405
$$

Le débit solide peut donc s'évaluer par la formule :

$$
\sqrt[3]{\frac{\mathrm{G}}{\rho^{\prime} \sqrt{\left(\rho^{\prime}-\rho\right) / ?} \sqrt{h^{3}}}}=\left[0,06715(d / h)^{2 / 3}+0,01405\right] \frac{\mathrm{V}}{\sqrt{\left(\rho^{\prime}-\rho\right) / \varphi} \sqrt{h}}-2,45(d / h)^{2 / 3}
$$

ou, en élevant au cube et en introduisant $g$, accélération de la pesanteur, pour donner a la formule un visage adimensionnel :

$\frac{G}{\rho^{\prime} \sqrt{\left(\rho^{\prime}-\rho\right) / \rho} \sqrt{g h^{3}}}=\left\{\left[0,667(d / h)^{2 / 3}+0,14\right] \frac{\mathrm{V}}{\sqrt{\left(\rho^{\prime}-\rho\right) / \rho} \sqrt{h}}-0,778(d / h)^{2 / 3}\right\}^{3}$

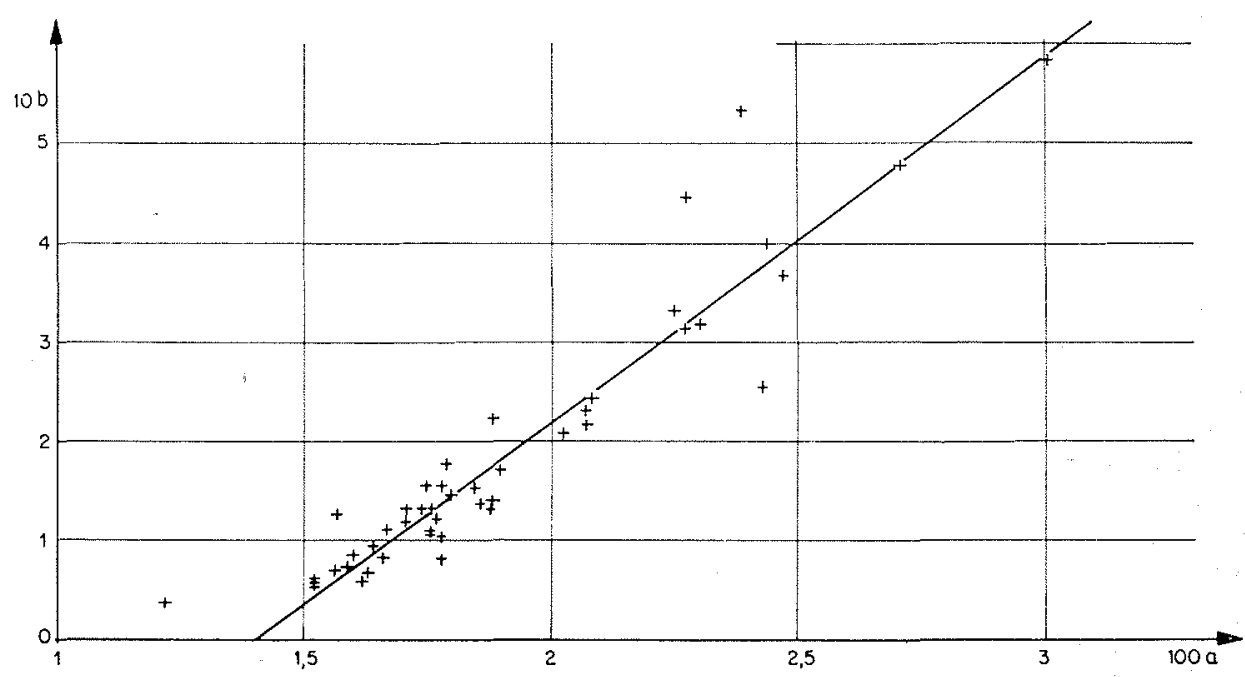

Fig. 4 


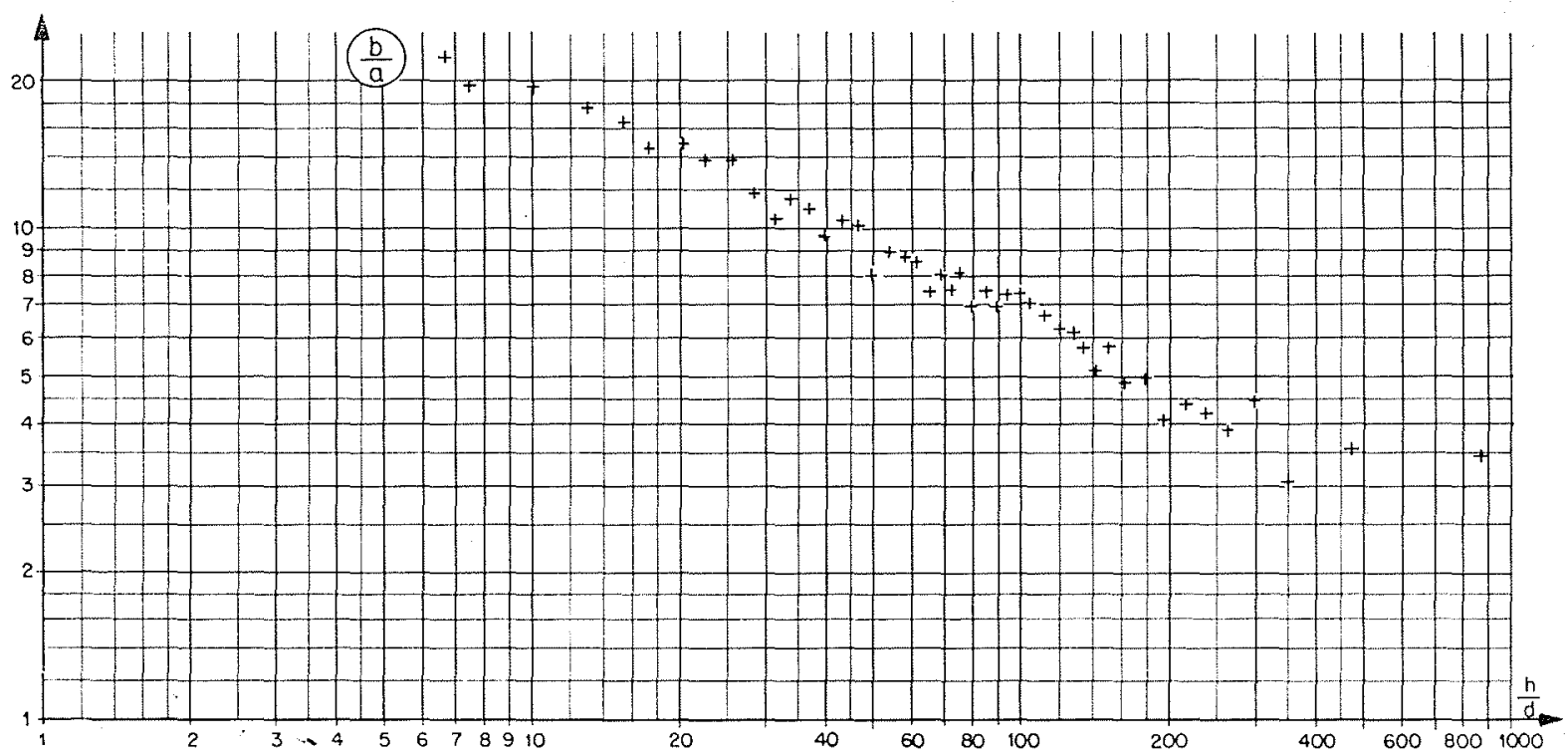

Firi. 5

Nous avons vu plus haut que $a$ dépendait linéairement de $b$. Le faisceau de droites $x=a l j-b$ passe done par un point fixe. Ecrivons : $x=\left[0,06715(d / h)^{2 / 3}+0,01405\right] y-2,45(d / h)^{2 / 3}$ ou aussi :

$(d / h)^{2 / 3}=(x-0,01405 y) /(0,06715 y-2,45)$

La valeur de $d / h$ est indéterminée lorsque le numérateur et le dénominateur sont nuls :

$$
\begin{aligned}
& x=0,513 \\
& y=36,5
\end{aligned}
$$

soit, avec les groupements sans dimension :

$$
\begin{gathered}
\sqrt[3]{\frac{G}{\rho^{\prime} \sqrt{\left(\rho^{\prime}-\rho\right) / \rho} \sqrt{g h^{3}}}}=0,164 \\
\frac{V}{\sqrt{\left(\rho^{\prime}-\rho\right) / \rho} \sqrt{g h}}=1,16
\end{gathered}
$$

Autrement dit, à la valeur 1,16 de :

$$
\frac{v}{\sqrt{\left(c^{\prime}-\rho\right) / ? \vee} \overline{g h}}
$$

correspond une valeur unique de :

$$
\frac{G}{\rho^{\prime} \vee\left(\rho^{\prime}-\rho\right) / \rho} \sqrt{g h^{3}}
$$

donc aussi de $G / Q$, la concentration.

Nous avons porté ce point fixe (carré plein) sur chacune de nos «pages ». Le lecteur peut se rendre compte qu'il se place bien parmi les points de mesure. La signification physique de ce résultat reste cependant à trouver.
En raison des incertitudes relevées au début des droites, la formule proposée ne convient peut-être plus pour les petits charriages. Quant au début d'entraînement, il est caractérisé par la valeur de $b / a$ :

$$
b / a=\frac{\mathrm{V}}{\sqrt{\left(\rho^{\prime}-\rho\right) / \rho} \sqrt{g h}}
$$

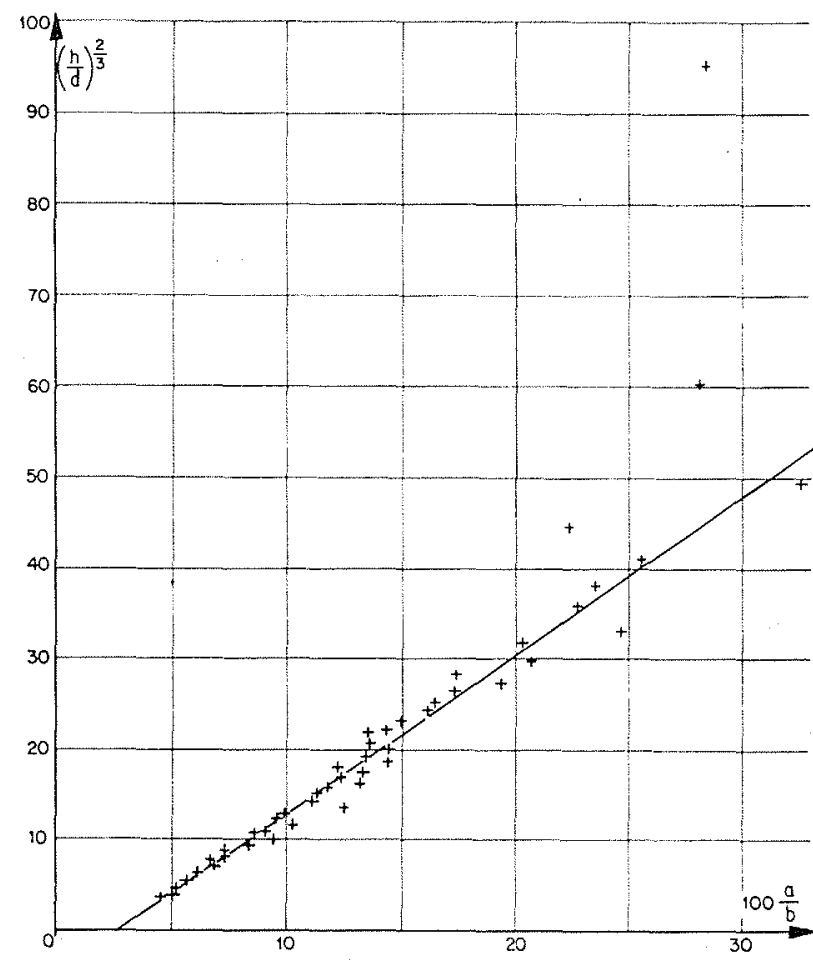

FIG. 6 
dont la représentation en coordonnées logarithmiques (fig. 5) présente une pente comprise entre 0,4 et 0.5 . En fait, elle n'est pas constante et semble augmenter lorsque $h / d$ croit, ce qui est en bon accord avec les exigences de notre formule. Il a été trouvé plus haut :

$$
a=0,02741 b+0,01405
$$

Ceci peut s'écrire, si l'on remplace $b$ par sa valeur $2,45(d / h)^{2 / 3}$ :

$$
100 a / b=2,74+0,573(h / d)^{2 / 3}
$$

relation linéaire entre $100 a / b$ et $(h / d)^{2 / 3}$. Nous avons donc porté les résultats trouvés pour $a$ et $b$ dans le système d'axes $a / b,(h / d)^{2 / 3}$ (fig. 6 ). La courbe obtenue semble effectivement être une droite.

Nous écrivons, pour le début d'entrainement :

$$
\frac{V}{\sqrt{\left(\rho^{\prime}-\rho\right) / \rho} \sqrt{g h}}=\frac{5,53}{(h y d)^{2 / 3}+4,75}
$$

Les groupements dont nous nous sommes servis ne sont évidemment pas exclusifs: Si nous avons évité d'utiliser la pente, c'est surtout pour des raisons de commodité. Elle est, en effet, souvent mal connue et, de plus, elle est rapidenient faussée dès que l'écoulement n'est plus uniforme.

Il serait, par exemple, possible de remplacer les groupements :

par :

$$
\frac{V}{\sqrt{\left(\rho^{\prime}-q\right) / p} \sqrt{g h}} \text { et } h / d
$$

$$
\frac{h i}{d\left(\rho^{\prime}-\rho\right) / p} \text { ou } \frac{i}{\left(\rho^{\prime}-p\right) / \rho}
$$

Dès lors, nous pouvons graduer les droites $h / d=C^{\text {te }}$ de notre représentation en valeurs d'un des deux derniers groupements. C'est ce que nous avons essayé dans la dernière partie de l'étude.

Il est, bien entendu, possible d'affecter la formule proposée des corrections habituelles pour tenir compte de l'effet des parois, des irrégularités du fond, etc. De mème, la section d'un lit naturel peut se diviser en troncons élémentaires où la profondeur peut être considérée comme constante.

Rappelons, d'autre part, que la vitesse $V$ entrant dans les formules a été choisie égale à la vitesse moyenne résultant de la division du débit par la section.

Ainsi que nous le proposions plus haut, nous avons examiné la variation d'un groupement contenant la pente en fonction d'autres paramètres. Pour simplifier les calculs, nous avons choisi de tracer les courbes $i /\left[\left(p^{\prime}-\rho / p\right)\right]$ en fonction de $V /\left[\sqrt{\left(\rho^{\prime}-0\right) / 0} \sqrt{h]}\right.$ pour des valeurs constantes de $h / d$.
Partant de l'idée qu'en l'absence de charriage, les points devaient être voisins de la droite déterminée par la formule de Manning :

$$
\mathrm{V}=\mathrm{C}(h / d)^{1 / 6} \sqrt{h i},
$$

où les masses spécifiques n'interviennent pas, les axes du système de coordonnées ont été cotés en :

$$
\frac{V}{\sqrt{\left(\rho^{\prime}-p\right) / p} \sqrt{h}} \text { et } \sqrt{\frac{i}{\left(\rho^{\prime}-p\right) / \rho}}
$$

11 est aisé de se rendre compte que la formule de Manning conduit, dans le système d'axes proposés, à une droite. Or, nous connaissions un point de cette droite, à savoir le point correspondant aù début d'entraînement. Nous semblions donc armés pour vérifier, partiellement du moins, la loi de Manning, et, d'autre part, pour préciser la transition enlre l'absence et la présence d'un charriage. En fait, les résultats en eau claire nous ont fait défaut de façon complète et les points affectés d'un transport solide correspondant à une faible valeur de $\sqrt{i /\left[\left(o^{\prime}-p\right) / e\right]}$ étaient trop dispersés pour permettre des affirmations nettes (voir le groupe de figures $n^{\circ} 7$ ).

Quelques «pages 》 montrent une dispersion importante, due, pensons-nous, à l'imprécision résultant de la mesure de $i$. Il nous a semblé illusoire de vouloir porter les points sur une courbe de degré supérieur à 1, et cela d'autant plus que les «pages $»$ à dispersion faible s'accommodent bien de la représentation par une droite.

Nous avons ainsi, pour chaque «page », recherché la droite représentant le mieux possible les résultats. Rappelons que chaque «page» correspond à une faible variation de $h / d$ et que $h / d$ a été supposé constant et égal à une certaine valeur moyenne.

Comme le montre la figure 8, les coefficients déterminant les droites $h / d=\mathrm{C}^{\text {te }}$ ne varient pas de facon simple en fonction de $h / d$. Aussi nous sommes-nous contentés de rechercher, pour diverses valeurs de $\sqrt{i /\left[\left(\rho^{\prime}-\rho\right) / \rho\right]}$ les valeurs correspondantes moyennes des $V /\left[\sqrt{\left(\rho^{\prime}-\rho\right) / \rho} V h\right]$, telles qu'elles résultent de la représentation par une droite, et de les reporter sur la figure 9.

Certains détails qui n'ont pas été portés sur la figure 9 nous font penser que les courbes $\sqrt{i /\left[\left(\rho^{\prime}-q\right) / 0\right]}$ se déforment comme il est indiqué ci-dessous.

La figure 10, enfin, a été tracée dans un système d'axes aux cotes adimensionnelles. $Y$ ont été visualisées les courbes $\sqrt{i /\left[\left(q^{\prime}-p\right) / q\right]}$ de la figure 8 et les courbes $h / d=\mathrm{C}^{\text {te }}$ correspondant a certaines valeurs entières de $h / d$.

Cet abaque permet ainsi, en partant de la con- 


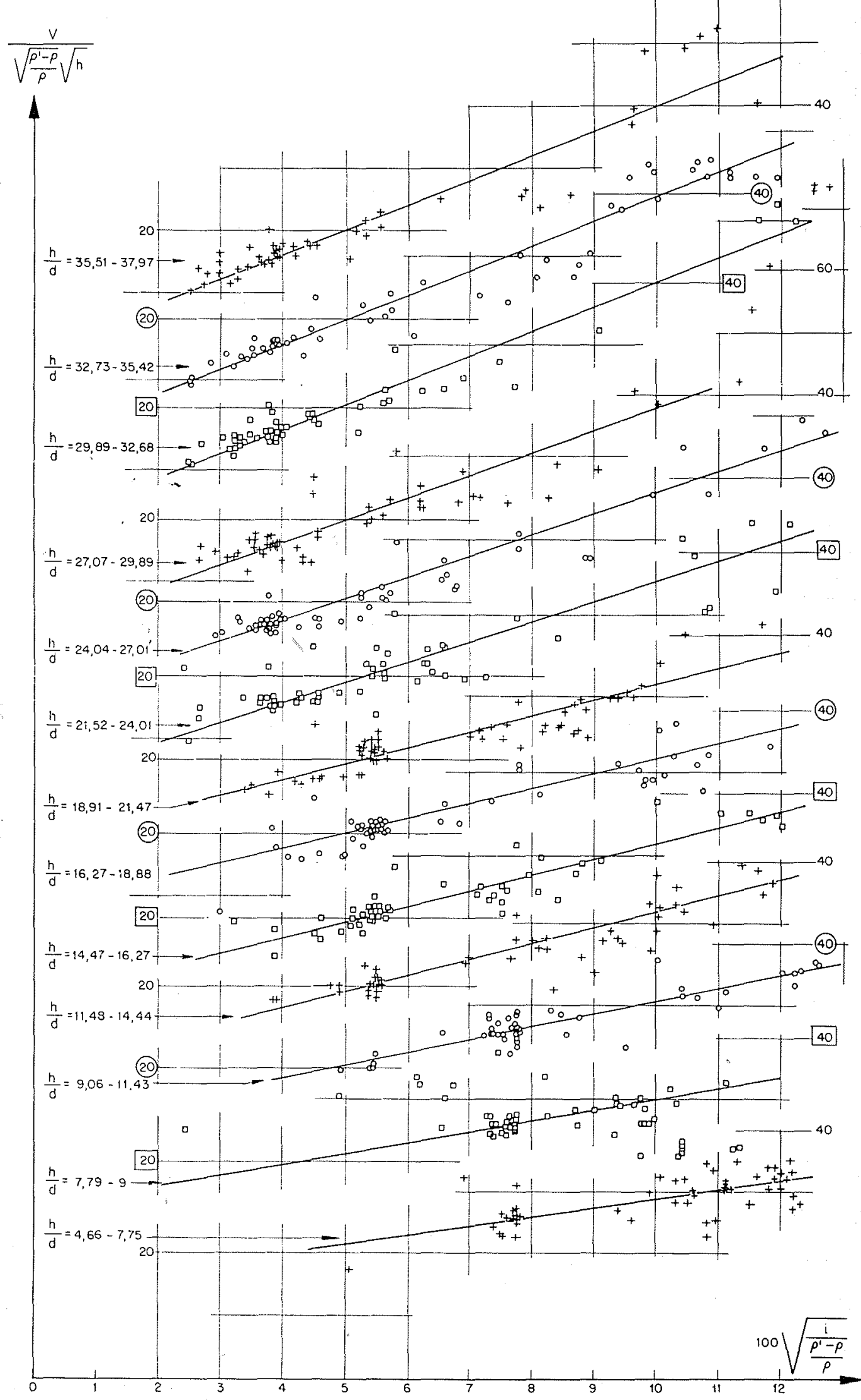

Fig. 7. - Planche I «Pages» 1 à 13. 


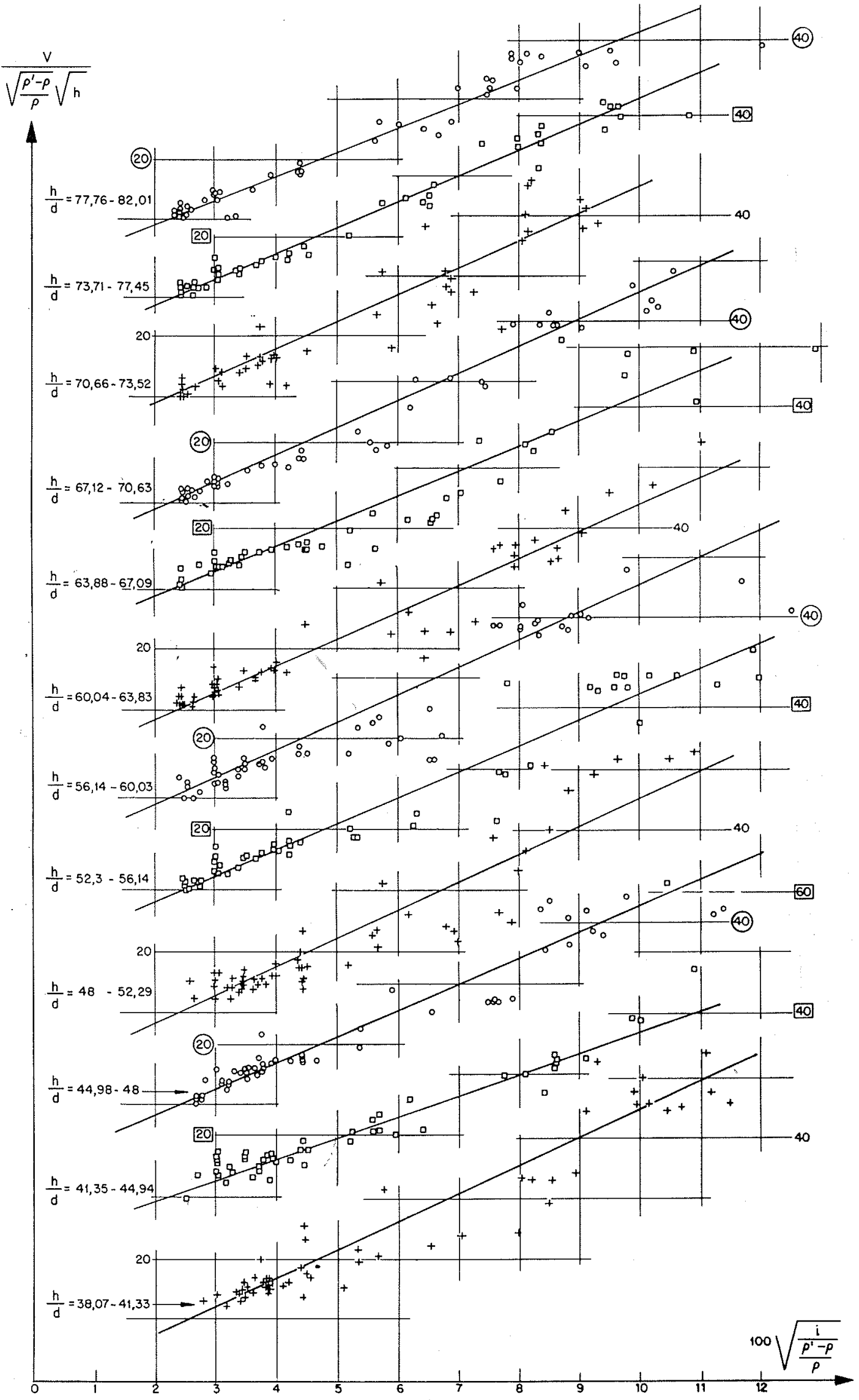

Fig, 7. - Planche II «Pages» 14 à 25. 


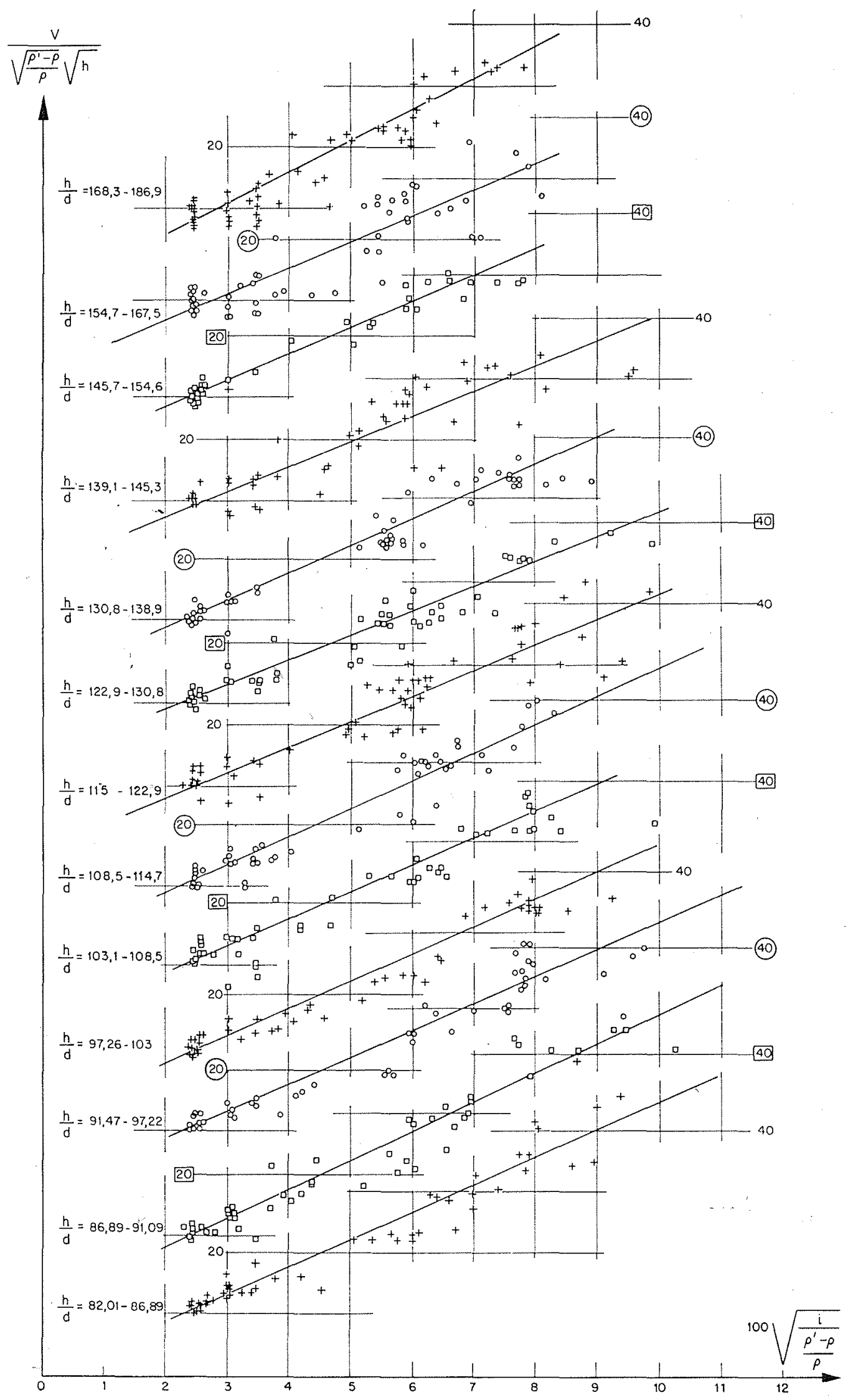

Fig, 7. - Planche III «Pages» 26 à 38. 


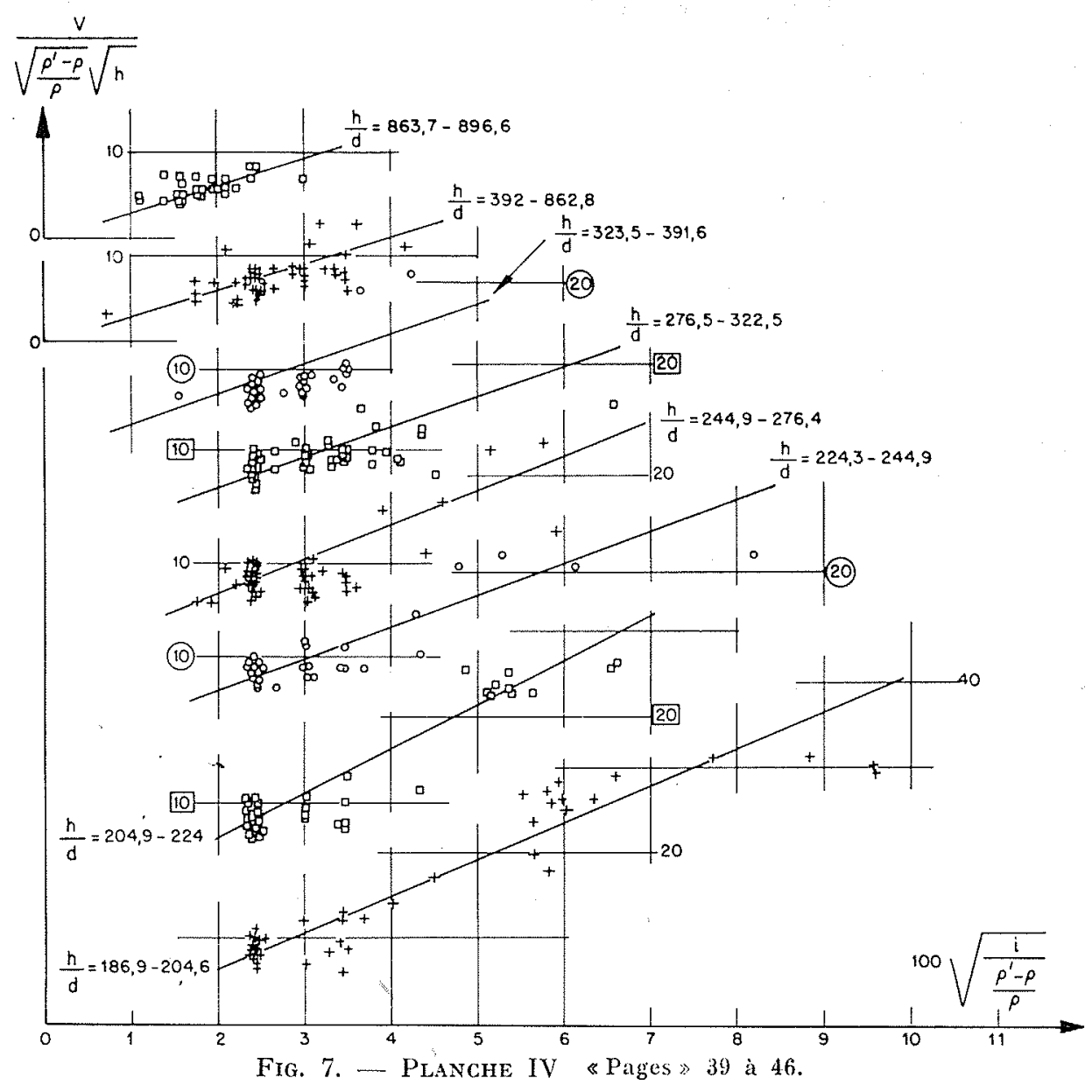

naissance de deux quelconques des quatre groupements :

$\frac{\mathrm{G}}{\sqrt{\left(\rho^{\prime}-g\right) / \mathrm{q}} \sqrt{g h^{3}}}, \frac{\mathrm{V}}{\sqrt{\left(\rho^{\prime}-q\right) / \rho} \sqrt{g h}}, h / d, \frac{i}{\left(\rho^{\prime}-\rho\right) / \rho}$

de trouver les deux autres.

Les notions exposées au cour's de cette étude concernent essentiellement le charriage. Il res- terait, entre autres, à examiner leur application à l'entrainement solide en suspension.

Des résultats de mesure obtenus par MeyerPeter, Ho, Knox, Liu et Carter, Linton, Schaffernak, Shields, Chang, Indri, Nakayama, certains résultats de l'U.S.W.E.S. et de Casey sont men tionnés mais non reproduits dans l'ouvrage de Johnson. Ils auraient peut-être permis de préciser certaines questions restées obscures et de vérifier les diverses affirmations de cette étude.

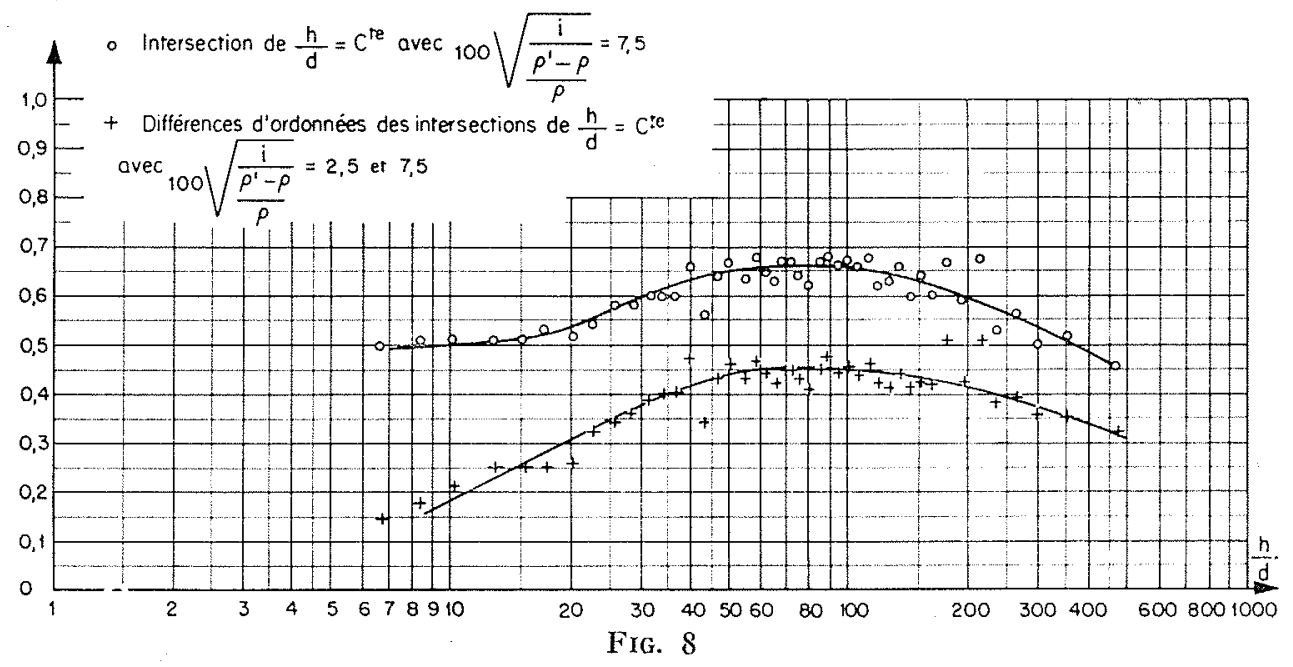




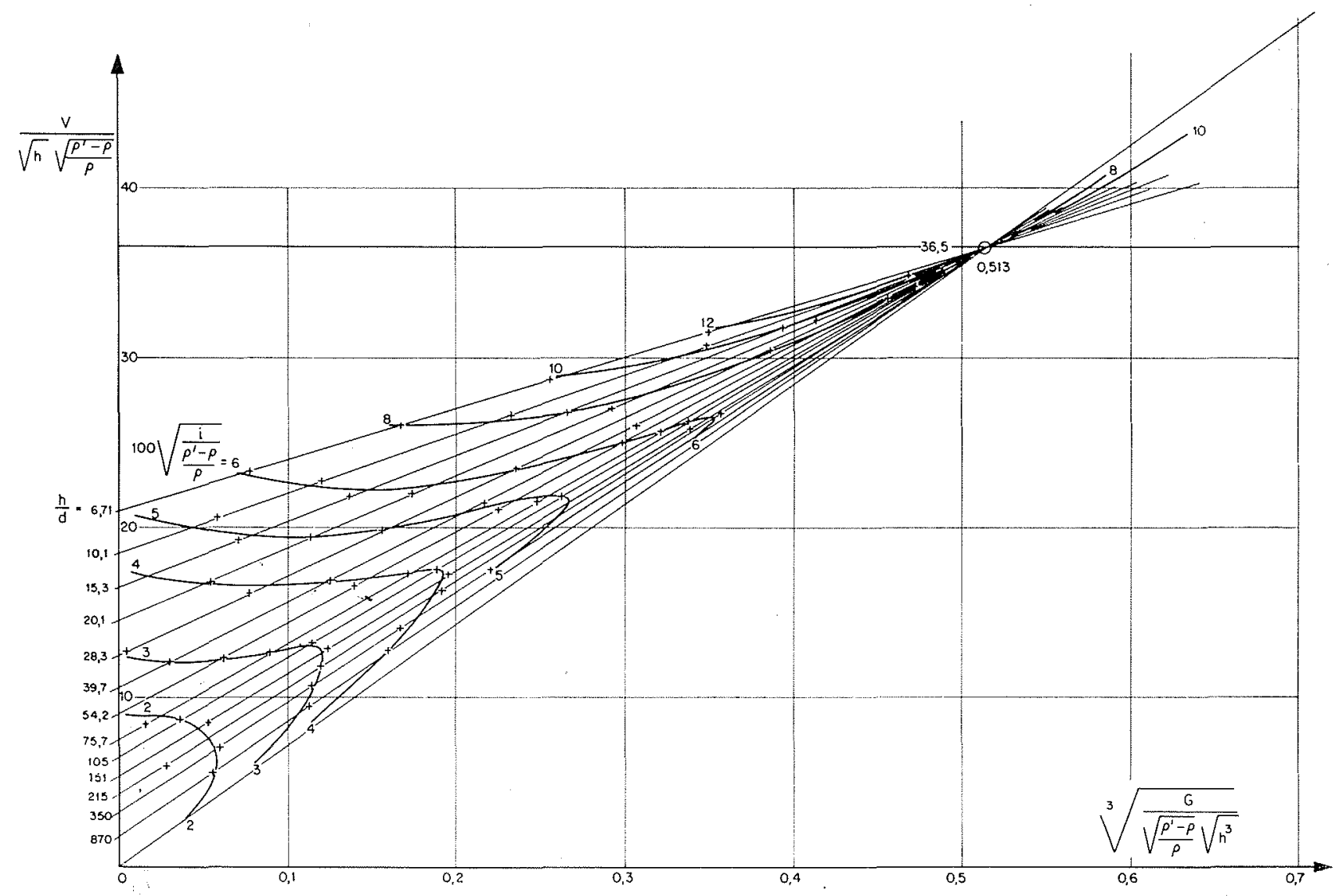

FIG. 9

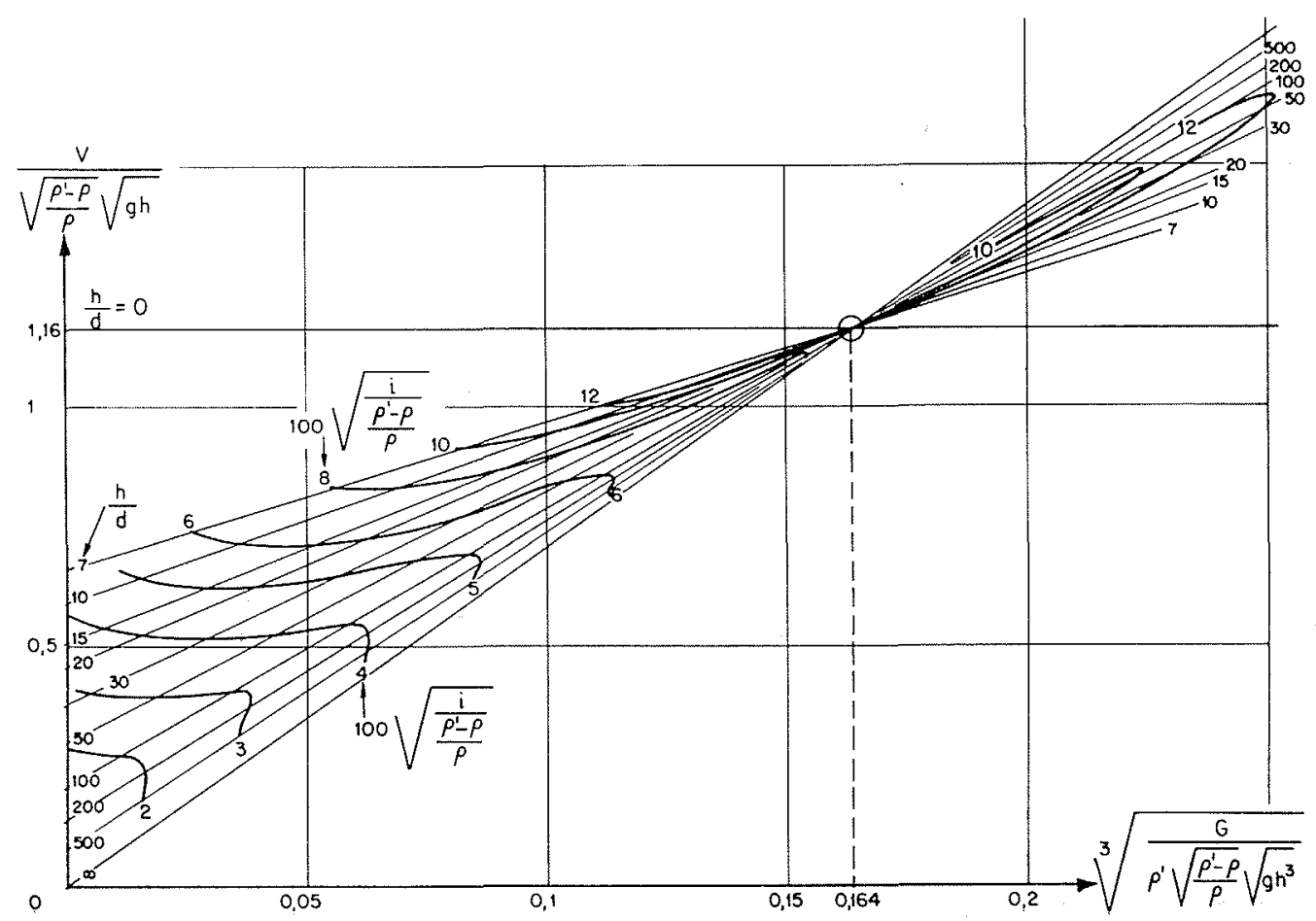

Fra, 10 


\title{
A formula for bed-load transportation
}

\author{
BY J. ROTTNER \\ ENGINEER AT THE SOGREAH, GRENOBLE \\ Texte français p. 285 \\ See French text for illustrations
}

\begin{abstract}
The bed-load movement of a natural waterway depends not only on universal flow factors such as the slope, discharge, etc., but also on elusive local conditions which vary from time to time and from place to place. A bed-load formula should therefore be based in the first place on laboratory flume tests. A publication on the subject by J. W. Johnson: "Laboratory investigations on bed-load transportation and bed roughness" gives some 2500 experimental results in handy form for research on the subject. These results are not only abondant but also diversified, and a formula derived
\end{abstract}

Research on bed-load movement in test flumes, and more generally in rivers and streams, has produced a large number of formulae. The problem has been investigated by such eminent authorities as Meyer-Peter, Einstein, Schoklitsch, Kalinske, Wilhelm, Du Boys, Rindlaub, Kramer and others. With very few exceptions, these authors neglect suspended loads in their consideration of solid transportation, and we shall proceed along the same lines.

In the first part of the article, solid discharge will be evaluated as a function of factors to be defined. Next, the flow velocity will be determined as a function of these same factors, and finally both these variables, solid discharge and flow velocity, will be plotted on a graph in terms of the same factors.

Parameters used by the above authors include the following:

\begin{abstract}
from them can be regarded as having a solid, critically sound backing.

A formula is in fact proposed, giving the bedload discharge as a function of the flow parameters. A chart aids easy practical ase. Subsequently the variation of the mean velocity of flow of water accompanying the bed-load transportation is examined and the results graphed on a chart which is of uider application than the former one. This enables the solid flow and the mean water velocity to be found from the slope, the flow depth and the grain size.
\end{abstract}

$h$ : depth of water,

$i$ : slope,

$v$ : mean water velocity,

$\tau=\gamma h i$ : tractive force,

$\mathrm{U}_{*}=\sqrt{\tau / 0}$ : "shear velocity",

$d$ : a grain dimension,

$\mathrm{Q}$ : liquid discharge,

W : width,

$\rho^{\prime}$ : specific mass of grain.

etc...

It seems definite from a very first consideration of the problem that calculation of the the solid discharge in a river or stream can be attempted only in a cross-section in which all the flow parameters are well defined. The 
simplest case, which is the one investigators nearly always consider, is a rectangular crosssection of well-determined width and depth, in which the flow is uniform. As soon as one departs from these conditions, the definition of several factors involved, such as the slope and the size of the cross-section, becomes arbitrary and this in turn cannot but make any calculations unreliable. In the following, we shall restrict ourselves to these ideal conditions.

It is known that in a cross-section that is much wider than deep, the flow involves only one dimension. In other words, wall effects can be neglected, or need at most be considered only in the immediate vicinity of the walls. The solid discharge can therefore be taken as constant throughout the whole width in which flow is occurring, and therefore does not depend on this dimension. We shall also assume these ideal conditions. A suitable way of taking wall effects into account could perhaps be found later on by an extension of the present work.

The solid discharge per unit width is determinod if the following are given :

$$
\begin{aligned}
& h \text {, depth, } \\
& i \text {, slope, } \\
& d \text {, grain size and density, also form factors } \\
& \quad \text { if applicable. }
\end{aligned}
$$

The physical constants $\circ$ and $g$, and $v$ (the viscosity).

For a non-uniform material, $d$ expresses a mean dimension. We shall see later on that the calculation of our groups of parameters with the experimental values of $d$ produces a set of points in which those relating to a uniform $d$ cannot be distinguished from the others. This seems to indicate that the mean grain diameter can be defined in such a way that the solid discharge can be calculated to a degree of approximation that is proportionate to the degree of accuracy usually associated with this type of calculation.

By knowing the above factors, we can also determine the mean flow velocity, or better still the liquid discharge per unit width, so that :--

and :

$$
\mathrm{Q}=f_{1}\left(h, i, d, ?^{\prime}, \rho, g, v\right)
$$

$$
\mathrm{G}(\text { solid discharge })=f_{2}\left(h, i, d, \rho^{\prime}, \rho, g, y\right)
$$

Eliminating $i$ from the above two formal relations, we obtain :--

$$
\mathrm{G}=f\left(\mathrm{Q}, h, d, \rho^{\prime} \rho, g, \nu\right)
$$

Dimensional analysis applied to these values leads to a relationship between the following parameters :-

$$
\frac{\mathrm{G}}{? \sqrt{g h^{3}}}, \frac{\mathrm{Q}}{\rho \sqrt{g h^{3}}}, \frac{h}{d}, \frac{\rho^{\prime}}{\rho}, \frac{v}{\sqrt{g h^{3}}}
$$

The second of these parameters is none other that the Froude number for the fluid. The first, a parameter of similar nature, can be considered as the Froude number for the grain.

Turbulence is clearly developed in most cases, so that the last of the above parameters no longer comes into play. This is known to be the case for clear water flowing, through a circular pipe, and the same assumption would appear to be justified in the present case.

One is therefore left with the following:--

$$
\frac{\mathrm{G}}{\rho \sqrt{g h^{3}}}, \frac{\mathrm{Q}}{\rho \sqrt{g h^{3}}}, \frac{v}{\sqrt{g h}}, \frac{h}{d}, \frac{\rho^{\prime}}{?}
$$

$\mathrm{G} / ? \sqrt{g h^{3}}$ can be replaced by $\mathrm{G} / \mathrm{f}^{\prime} \sqrt{g h^{3}}$ by multiplying the first of the above by $o / \rho^{\prime}$, the latter parameter related to the solid volumetric discharge.

The formulae and experience of the various authorities on the subject also show that $\rho^{\prime} /$ ? is intimately connected with the other parameters. If the forces acting on a grain are examined in a simple way, it will be seen that the specific mass of the material acts through $g\left(o^{\prime}-p\right) / e$ (ratio of apparent weight to hydrodynamic force). It has therefore been assumed that $\rho^{\prime} / \rho$ need only be considered in this form, which gave the following parameters:

$$
\begin{aligned}
& \frac{\mathrm{G}}{\rho^{\prime} \sqrt{g h^{3}} \frac{\mathrm{Q}\left(\rho^{\prime}-\rho\right) / \rho}{\rho}}, \frac{\mathrm{Q}}{\frac{\mathrm{g} h^{3}\left(\rho^{\prime}-\rho\right) / \rho}{\mathrm{V}}}, \\
& \frac{\mathrm{V}}{\sqrt{g h\left(\rho^{\prime}-\rho\right) / \rho}}, \frac{h}{d}
\end{aligned}
$$

The results published by J.W. Johnson in "Laboratory investigations on bed-load transportation and bed roughness" were available for checking these assumptions. These data refer to measurements made by Gilbert, C.H. MacDougall, S.D. Chyn, Jorissen, U.S.W.E.S., T.Y Liu, C.H. Yen, M.P. O’Brien, H.C. Casey, Pang-Yung Ho.

The characteristics of the materials investigated by the above authors are included in the opposite table.

In this way, we were able to avail ourselves of more than 2,500 test measurements, which were then classified in terms of increasing $h / d$ values. These results were grouped on 46 "pages", each containing some 50 points. The calculations were carried out on an IBM 650 magnetic-drum computer. (See table on the page 304.)

On each "page", except on the last two, where 


\begin{tabular}{|c|c|c|c|c|c|c|c|}
\hline AUTHOR & MATERIAL & $\begin{array}{l}\text { MEAN } \\
\text { DHAMETER } \\
\text { in nM }\end{array}$ & $\begin{array}{l}\text { SPECIFIQUE } \\
\text { GRAVITY }\end{array}$ & AUTHOR & MATERIAL & $\begin{array}{c}\text { MEAN } \\
\text { DIAMETFR } \\
\text { in mm }\end{array}$ & $\begin{array}{c}\text { SPECIFIQUE } \\
\text { GRAVITY }\end{array}$ \\
\hline $\begin{array}{l}\text { CHYY ...... } \\
\text { JORISSEN ... } \\
\text { U.S.W.E.S. . . }\end{array}$ & $\begin{array}{l}\text { artificial } \\
\text { mixture } \\
\text { artificial } \\
\text { mixture } \\
\text { artificial } \\
\text { mixture } \\
\text { artificial } \\
\text { mixture } \\
\end{array}$ & $\begin{array}{l}0.305 \\
0.375 \\
0.506 \\
0.786 \\
1.71 \\
3.17 \\
4.938 \\
7,010 \\
\\
0.66 \\
1.01 \\
1,44 \\
\\
0.849 \\
0.840 \\
0.847 \\
\\
0.72 \\
0.93 \\
0.586 \\
0.541 \\
0.525 \\
0.506 \\
0.483 \\
0.347 \\
0.310 \\
0.205 \\
4.077 \\
0.853 \\
0.794 \\
0.715 \\
1.224 \\
1.162 \\
1.008 \\
0,986 \\
1.067 \\
1.052 \\
1.066 \\
0.732 \\
0.738 \\
0.759 \\
0.367 \\
0.498 \\
0.691 \\
0.976\end{array}$ & 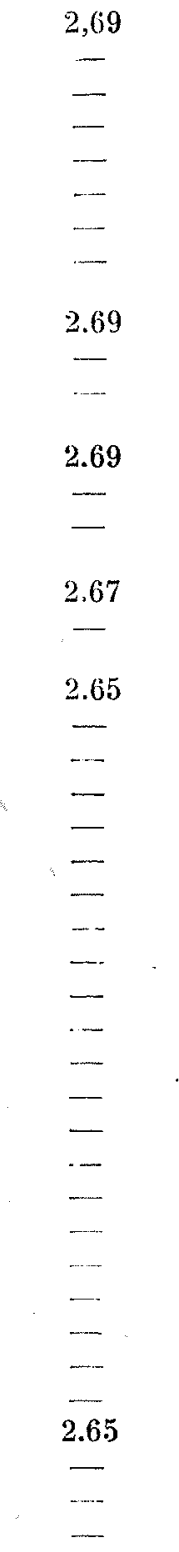 & 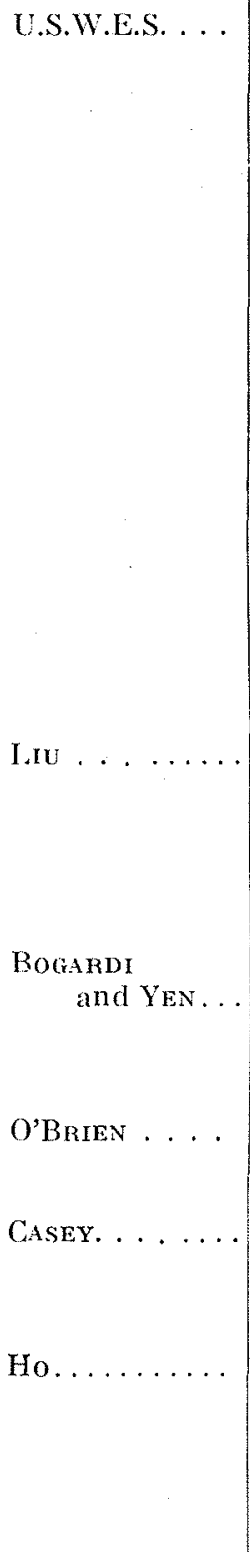 & $\begin{array}{c}\text { natural } \\
\text { mixture } \\
\text { uniform } \\
\text { artificial } \\
\text { mixture } \\
\text { artificial } \\
\text { mixture }\end{array}$ & $\begin{array}{l}0.597 \\
1.067 \\
0.908 \\
1.329 \\
3.3 \\
1.097 \\
3.197 \\
1.485 \\
2.61 \\
1.168 \\
3.963 \\
1.147 \\
2.777 \\
1.317 \\
3.593 \\
0.899 \\
3.526 \\
1.249 \\
3.112 \\
1.165 \\
4.4 \\
3.4 \\
2.3 \\
1.4 \\
3.6 \\
1.8 \\
\\
10.56 \\
7.12 \\
15.49 \\
0.366 \\
\\
2.455 \\
1.32 \\
\\
3.83 \\
4.64 \\
6.99 \\
2.18 \\
6.17 \\
1.55\end{array}$ & $\begin{array}{l}2.65 \\
1.85 \\
1.85 \\
1.74 \\
1.35 \\
1.35 \\
1.32 \\
1.32 \\
1.31 \\
1.31 \\
1.26 \\
1.26 \\
1.11 \\
1.11 \\
1.07 \\
1.07 \\
1.05 \\
1.05 \\
1.03 \\
1.03 \\
2.66 \\
- \\
- \\
- \\
-5 \\
- \\
2.63 \\
2.61 \\
2.64 \\
2.57 \\
2.70 \\
2.70 \\
- \\
- \\
- \\
- \\
\\
- \\
\\
-\end{array}$ \\
\hline
\end{tabular}

the points were too close together, the points have been plotted on the following coordinate system:

$$
y=\frac{\mathrm{V}}{\sqrt{h\left(\rho^{\prime}-\rho\right) / \rho}} x=\left[\frac{\mathrm{G}}{\rho^{\prime} \sqrt{h^{3}\left(\rho^{\prime}-\rho\right) / \rho}}\right]^{1 / 3}
$$

where:

$\mathrm{G}$ is in $\mathrm{gr} / \mathrm{sec}$. per centimetre width,

$\mathrm{V}$ is in $\mathrm{cm} / \mathrm{sec}$,

$h$, in centimetres.
The results are shown on figures 1 .

The points lie satisfactorily near straight lines expressed by $x=a y-b$, although on some "pages ", the initial part of the curve, at low values of $y$, seems to tend approach the $y$ axis perpendicularly. However, this trend was not marked enough, nor did it appear sufficiently often, to enable any definite conclusion to be drawn. A 


\begin{tabular}{|c|c|c|}
\hline Page & $h / d$ & Mean $h / d$ value \\
\hline 1 & $4.66-$ & 6.71 \\
\hline 2 & $7.79-9$ & 8.38 \\
\hline 3 & $9.06-11.43$ & 10.1 \\
\hline 4 & $11.48-14.44$ & 12.9 \\
\hline 5 & $14.47-16.27$ & 15.3 \\
\hline 6 & $16.27-18.88$ & 17.3 \\
\hline 7 & $18.91-21.47$ & 20.1 \\
\hline 8 & $21.52-24.01$ & 22.6 \\
\hline 9 & $24.04-27.01$ & 25.6 \\
\hline 10 & $27.07-29.89$ & 28.3 \\
\hline 11 & $29.89-32.68$ & 31.3 \\
\hline 12 & $32.73-35.42$ & 34 \\
\hline 13 & $35.51-37.97$ & 36.7 \\
\hline 14 & $38.07-41.33$ & 39.7 \\
\hline 15 & $41.35-44.94$ & 43 \\
\hline 16 & $44.98-48$ & 46.6 \\
\hline 17 & $48-52.29$ & 49.8 \\
\hline 18 & $52.3-56.14$ & 54.2 \\
\hline 19 & $56.14-60.03$ & 58.1 \\
\hline 20 & $60.04-63.83$ & 61.5 \\
\hline 21 & $63.88-67.09$ & 65.3 \\
\hline 22 & $67.12-70.63$ & 69 \\
\hline 23 & $70.66-73.52$ & 71.9 \\
\hline 24 & $73.71-77.45$ & 75.7 \\
\hline 25 & $77.76-82.01$ & 79.6 \\
\hline 26 & $.82 .01-86.89$ & 84.5 \\
\hline 27 & $86.89-91.09$ & 89.1 \\
\hline 28 & $91.47-97.22$ & 93.7 \\
\hline 29 & $97.26-103$ & 105 \\
\hline 30 & $103.1-108.5$ & 112 \\
\hline 31 & $108.5-114.7$ & $\$ 9.7$ \\
\hline 32 & $115-122.9$ & 119 \\
\hline 33 & $122.9-130.8$ & 126 \\
\hline 34 & $130.8-138.9$ & 134 \\
\hline 35 & $139.1-145.3$ & 142 \\
\hline 36 & $145.7-154.6$ & 151 \\
\hline 37 & -167.5 & 161 \\
\hline 38 & -186.9 & 178 \\
\hline 39 & $186.9-204.6$ & 193 \\
\hline 40 & $204.9-224$ & 215 \\
\hline 41 & $224.3-244.9$ & 233 \\
\hline 42 & $244.9-276.4$ & 262 \\
\hline 43 & $276.5-322.5$ & 298 \\
\hline 44 & $323.5-391.6$ & 350 \\
\hline 45 & $392-862.8$ & 472 \\
\hline 46 & $863.7-896.6$ & 870 \\
\hline
\end{tabular}

similar remark also applies to the other end of the straight line.

The considerable scatter on "page" 1 is explained by the large variations occurring in the $(h / d)$ values (from 4.66 to 7.75 ).

In order to obtain an element of comparison from which the scatter of the points around the straight line could be assessed, the points on "pages" 12, 24, 30, and 35 have been replotted on a graph using the groups in Meyer-Peter's formula as coordinates, as follows :-

$$
\begin{aligned}
\gamma_{w}\left(\mathrm{Q}_{s} / \mathrm{Q}\right)\left(k_{s} / k_{r}\right)^{3 / 2} h i=0.047 & \gamma_{s}^{\prime \prime} d \\
& +0.25\left(\gamma_{w} / g\right)^{1 / 3} g_{s}{ }^{\prime \prime 2 / 3}
\end{aligned}
$$

where:

$$
\begin{aligned}
& \gamma_{w}=g \rho, \\
& \vartheta^{\prime \prime}{ }_{s}=g\left(\rho^{\prime}-\rho\right) \\
& g^{\prime \prime}{ }_{s}=\text { solid discharge per unit width, } \\
& \text { weighed under water. }
\end{aligned}
$$

Since we ourselves had not applied any correction to allow for such things as wall effect, the possible existence of "dunes", or changes in the value of $(h / d)$ on a given "page", MeyerPeter's formula was reduced to a simpler form as follows:

$$
h i / d=\mathrm{A} \gamma^{\prime \prime}{ }_{s}+\mathrm{B}\left(g_{s}^{\prime \prime \prime} / h\right)^{2 / 3}(h / d)
$$

or :

$$
\frac{h i}{d\left(\rho^{\prime}-\rho\right) / \rho}=\mathrm{A}+\mathrm{B}\left[\frac{\mathrm{G}}{\rho^{\prime} \sqrt{\left[\left(\varphi^{\prime}-\rho\right) / \rho\right] h^{3}}}\right]^{2 / 3} h / d
$$

Furthermore, since $(h / d)$ is assumed to be constant for each "page", we are left with the following parameters :

$$
\frac{h i}{d\left(\rho^{\prime}-\rho\right) / \rho} \text { and }\left[\frac{\mathrm{G}}{\rho^{\prime} \sqrt{\left[\left(\rho^{\prime}-\rho\right) / \rho\right] h^{3}}}\right]^{1 / 3}
$$

The exponent $1 / 3$, was chosen for the graphs in order to render the various degrees of scatter comparable (see figs. 2).

As has already been pointed out, straight lines could apparently be used equally well instead of the curves. The few deviations at both ends of these lines did not appear to be large enough to warrant our discarding this method of representation; besides, it is always possible to make additional measurements in order to define these points more accurately and to use a more complex form than a straight line if required. It is noteworthy in this connection, that Meyer-Peter's formula reduces to a linear relation between $x^{2}$ and $y^{2}$ if transformed by Manning's formula :--

$$
\mathrm{V}=(h / d)^{1 / 6} \sqrt{h i}
$$

As it happens, several Russian authors have also suggested formulae in which the parameters are grouped in the same way, such as I.L. Levy, who uses the following :

$$
\begin{aligned}
G / \sqrt{h^{3}}=(\boldsymbol{u} / \sqrt{g d})^{3}(h / d)^{3 / 2} & \\
& {\left[1-a(\sqrt{g d} / u)(h / d)^{0.10}\right](u / \sqrt{h}) }
\end{aligned}
$$

which can be written as :

$$
\mathrm{G} / \sqrt{h^{3}}=(u / \sqrt{h})^{3}\left[(u / \sqrt{h})-a(h / d)^{-0,34}\right]
$$


or, using our variables $x$ and $y$ :

$$
x^{3}=y^{3}\left[y-a(h / d)^{-0,34}\right]
$$

By using the method of least squares, optimum values were calculated for coefficients $a$ and $b$ in $x=a y-b$, from which the characteristic $b / a$ for the incipient entrainment condition was deduced :

\begin{tabular}{|c|c|c|c|c|}
\hline Page & $h / d$ & $100 a$ & $10 b$ & $b / a$ \\
\hline 1 & 6.71 & 2.39 & 5.33 & 22.3 \\
\hline 2 & 8.38 & 2.28 & 4.47 & 19.6 \\
\hline 3 & 10.1 & 3.01 & 5.84 & 19.4 \\
\hline 4 & 12.9 & 2.71 & 4.76 & 17.6 \\
\hline 5 & 15.3 & 2.44 & 3.98 & 16.3 \\
\hline 6 & 17.3 & 2.25 & 3.29 & 14.6 \\
\hline 7 & 20.1 & 2.47 & 3.65 & 14.8 \\
\hline 8 & 22.6 & 2.3 & 3.16 & 13.7 \\
\hline 9 & 25.6 & 2.27 & 3.11 & 13.7 \\
\hline 10 & 28.3 & 1.88 & 2.23 & 11.9 \\
\hline 11 & 31.3 & 2.43 & 2.54 & 10.5 \\
\hline 12 & 34 & 2.08 & 2.41 & 11.6 \\
\hline 13 & 36.7 & 2.07 & 2.28 & 11 \\
\hline 14 & 39.7 & 1.79 & 1.74 & 9.69 \\
\hline 15 & 43 & 2.07 & 2.15 & 10.4 \\
\hline 16 & 46.6 & 2.02 & 2.04 & 10.1 \\
\hline 17 & 49.8 & 1.57 & 1.26 & 8.01 \\
\hline 18 & 54.2 & 1.9 & 1.7 & 8.97 \\
\hline 19 & 58.1 & 1.75 & 1.55 & 8.82 \\
\hline 20 & 61.5 & 1.78 & 1.53 & 8.49 \\
\hline 21 & 65.3 & 1.74 & 1.3 & 7.48 \\
\hline 22 & 69 & 1.8 & 1.29 & 7.52 \\
\hline 23 & 71.9 & 1.71 & 1.45 & 8.03 \\
\hline 24 & 75.7 & 1.85 & 1.51 & 8.15 \\
\hline 25 & 79.6 & 1.77 & 1.23 & 6.95 \\
\hline 26 & 84.5 & 1.76 & 1.3 & 7.39 \\
\hline 27 & 89.1 & 1.71 & 1.19 & 6.96 \\
\hline 28 & 93.7 & 1.86 & 1.36 & 7.3 \\
\hline 29 & 99.7 & 1.88 & 1.39 & 7.37 \\
\hline 30 & 105 & 1.88 & 1.31 & 7 \\
\hline 31 & 112 & 1.67 & 1.11 & 6.66 \\
\hline 32 & 119 & 1.76 & 1.09 & 6.2 \\
\hline 33 & 126 & 1.76 & 1.07 & 6.08 \\
\hline 34 & 134 & 1.64 & 0.944 & 5.77 \\
\hline 35 & 142 & 1.6 & 0.824 & 5.14 \\
\hline 36 & 151 & 1.78 & 1.02 & 5.75 \\
\hline 37 & 161 & 1.59 & 0.769 & 4.83 \\
\hline 38 & 178 & 1.66 & 0.816 & 4.92 \\
\hline 39 & 193 & 1.52 & 0.615 & 4.05 \\
\hline 40 & 215 & 1.56 & 0.682 & 4.38 \\
\hline 41 & 233 & 1.63 & 0.693 & 4.26 \\
\hline 42 & 262 & 1.52 & 0.592 & 3.9 \\
\hline 43 & 298 & 1.78 & 0.793 & $4 .\{6$ \\
\hline 44 & 350 & 1.22 & 0.373 & 3.06 \\
\hline 45 & 472 & 1.52 & 0.542 & 3.56 \\
\hline 46 & 870 & 1.62 & 0.568 & 3.51 \\
\hline
\end{tabular}

Plotted logarithmically, the points for $b$ lie close to the straight line $b=2.45(d / h)^{2 / 3}$ : although the same cannot be said for $a$ or $(b / a)$; see figs. 3 and 5 . If however, $a$ is plotted against $b$ using Cartesian coordinates (see fig. 4), it is found that the points all lie close to the straight line expressed by :

$$
a=0.02741 b+0.01405
$$

and hence,

$$
a=0.06715(d / h)^{2 / 3}+0.01405
$$

In other words, the solid discharge can be obtained from the following relationship :

$$
\begin{aligned}
& \sqrt[3]{\frac{G}{\rho^{\prime} \sqrt{\left(o^{\prime}-o\right) / \%} \sqrt{h^{3}}}}=\left[0.06715(d / h)^{2 / 3}+0.01405\right] \\
& X-\frac{\mathrm{V}}{\sqrt{\left(\rho^{\prime}-\rho\right) / ?} \sqrt{h}}-2.45(d / h)^{2 / 3}
\end{aligned}
$$

Or, if the above is raised to the third power and if the acceleration due to gravity $g$ is in troduced in order to give the formula a non dimensional aspect :

$$
\begin{gathered}
\frac{G}{\rho^{\prime} \sqrt{\left(\rho^{\prime}-\rho\right) / \rho} \sqrt{g h^{3}}}=\left\{\left[0.667(d / h)^{2 / 3}+0.14\right]\right. \\
\left.\times \frac{V}{\sqrt{\left(\rho^{\prime}-\rho\right) / \rho} \sqrt{g h}}-0.778(d / h)^{2 / 3}\right\}
\end{gathered}
$$

We have already seen that $a$ is a linear function of $b$. The set of straight lines $x-a y-b$ therefore runs through a fixed point. Let:

$$
x=\left[0.06715(d / h)^{2 / 2}+0.01405\right] y-2.45(d / h)^{2 / 3}
$$
or :

$(d / h)^{2 / 3}=(x-0.01405 y) /(0.06715 y-2.45)$

The value of $(d / h)$ is indeterminate when both numerator and denominator are zero, i. e.

$$
\begin{aligned}
& x=0.513 \\
& y=36.5
\end{aligned}
$$

and, with the non-dimensional groups :

$$
\begin{gathered}
\sqrt[3]{\frac{\mathrm{G}}{\rho^{\prime} \sqrt{\left(\rho^{\prime}-\rho\right) / \rho} \sqrt{g h^{3}}}}=0.164 \\
\frac{\mathrm{V}}{\sqrt{\left(\rho^{\prime}-\rho\right) / \rho} \sqrt{g h}}=1.16
\end{gathered}
$$

In other words, there is only one value of

$$
\frac{G}{\rho^{\prime} \sqrt{\left(\rho^{\prime}-\rho\right) / \rho} \sqrt{g h^{3}}}
$$

and hence also of the concentration $G / Q$, for :

$$
\frac{\mathrm{V}}{\sqrt{\left(\rho^{\prime}-\rho\right) / \rho} \sqrt{g h}}=1.16
$$


We have shown this fixed point as a solid square on each of our "pages", and it will be obvious to the reader that it lies well within the measured points. The physical meaning of this result is however still unknown for the time being.

In view of the uncertainty at the origin of the straight lines, the proposed formula may not be applicable to cases where only small quantities of material are being conveyed. Incipient entrainment is characterised by the value of $b / a$ :

$$
b / a=\frac{V}{\sqrt{\left(\rho^{\prime}-0\right) / e} \sqrt{h l}}
$$

which, if plotted against logarithmic coordinates (see fig. 5) has a slope lying between 0.4 and 0.5. In actual fact, this slope is not constant, but seems to increase with $(h / d)$, which agrees well with the requirements of our formula. As we have already seen :

$$
a=0,02741 b+0.01405
$$

or, if $b$ is replaced by its value $2.45(d / h)^{2 / 3}$ :

$$
100(a / b)=2.74+0.573(h / d)^{2 / 3}
$$

which is a linear relation between $100 a / b$ and $(h / d)^{2 / 3}$. We therefore plotted the results obtained for $a$ and $b$ against $(a / b)$ and $(h / d)^{2 / 3}$ (fig. 6), obtaining what seems to all intents and purposes to be a straight line.

The incipient entrainment condition is expressed as follows :

$$
\frac{v}{\sqrt{\left(\rho^{\prime}-\rho\right) / \rho} \sqrt{g h}}=\frac{5.53}{(h / d)^{2 / 3}+4.75}
$$

The parameters used are obviously not exclusive. We have avoided using the slope mainly for reasons of convenience, for it is often not well known and rapidly becomes biased as soon as the flow ceases to be uniform.

It would be possible, for instance, to replace the dimensionless parameters:

$$
\frac{V}{\sqrt{\left(\rho^{r}-p\right) / \rho} \vee \overline{g h}} \text { and } h / d
$$

by :

$$
\frac{h i}{d\left(\rho^{\prime}-\rho\right) / \rho} \quad \frac{i}{\left(\rho^{\prime}-\rho\right) / \rho}
$$

The straight lines for $h / d=$ constant in our graph can then be graduated in terms of the values of one of the last two groups. This is, in fact, what we attempted in the final part of our investigation.

The usual corrections for wall effects, bed unevenness, etc., could of course be applied to the proposed formula, and similarly, the crosssection of a natural bed can be divided up into elementary sections in which the depth can be considered as constant.

It will also be recalled that the velocity $\mathrm{V}$ entering into the formulae was taken as equal to the mean velocity obtained by dividing the discharge by the cross-sectional area.

As suggested earlier on, we have also considered the variations of a given parameter containing the slope in terms of other parameters. In order to simplify the calculation we decided to plot the curves for $i /\left[\left(\rho^{\prime}-p\right) / p\right]$ in terms of $V /\left[\sqrt{\left(\rho^{\prime}-\rho\right) / \rho \vee} \bar{l}\right]$ for constant values of $(h / d)$.

Starting from the assumption that, if no materials were being conveyed, the points should lie close to the straight line determined by Manning's formula $V=\mathrm{C}(h / d)^{1 / 6} \sqrt{h i}$ where the specific gravities do not have to be considered, the following coordinates were selected for the system:

$$
\frac{V}{\sqrt{\left(\rho^{\prime}-\rho\right) / \varphi} \sqrt{h}} \text { and } \sqrt{\frac{i}{\left(\rho^{\prime}-\rho\right) / \varphi}}
$$

It is easy to see that Manning's formula corresponds to a straight line in the proposed coordinate system. Now we already know a point on this straight line, i.e. the point corresponding to incipient entrainment, and it seems at first sight that Manning's law could be checked, even if only partially, and that the transition between the state in which solid transport occurs and that in which it does not could be defined. As it happened, no clear-water results without bed movement were available and the points corresponding to solid transport occurring at low values of $\sqrt{i /\left[\left(q^{\prime}-p\right) / 0\right]}$ were too scattered to enable any definite inferences to be made (sce figs. 7).

Some of the "pages" show considerable scatter, which is probably due to inaccuracies in measuring $i$. It seemed pointless to attempt to plot the points on a curve of a higher degree than a straight-line relationship, all the more so because the "pages" on which little scatter occurs can be adequately represented by straight lines.

We therefore tried to find the straight line giving the best representation of the results for each "page". It will be recalled in this connection that each "page" relates to a small variation of $(h / d)$, and that $(h / d)$ was assumed to be constant and equal to a certain mean value.

As fig. 8 shows, the coefficients determining the straight lines for $h / d=$ Constant do not vary 
as a simple function of $(h / d)$. We therefore merely tried to find the mean values of

$$
\frac{\mathrm{V}}{\sqrt{\left(\varphi^{\prime} \cdots-\varphi\right) / \varphi} \sqrt{h}}
$$

corresponding to various values of $\sqrt{i /\left[\left(\rho^{\prime}-p\right) / \rho\right]}$ as obtained from the linear representation, and then to plot them as in fig. 9 .

Some of the details not shown on fig. 9 seem to imply that the curves are deformed as indicated below.

Fig. 10 was plotted on a coordinate system and expresses the $\sqrt{i /\left[\left(\rho^{\prime}-\rho\right) / e\right]}$ curves of fig. 8 and $h / d=$ Constant curves relating to certain whole values of $(h / d)$.

Therefore, if any two of the following four dimensionless parameters are known :

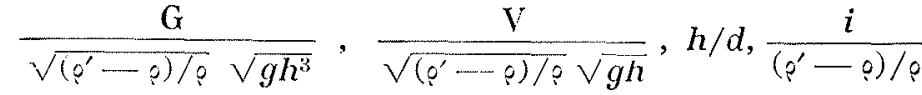

the other two can be determined from this graph.

The notions presented in this work apply strictly to the conveyance of materials not in suspension. Their application to the latter remains to be investigated as a separate subject.

Experimental results obtained by Meyer-Peter, Ho, Knox, Liu and Carter, Schaffernak, Shields, Chang, Indri, Nakayama, some of the U.S.W.E.S., and Casey's results are mentioned in Johnson's work, without however being reproduced. 'They might have enabled some of the outstanding obscure points to be detailed and the various statements made in this work to be confirmed.

\section{NOTRE FRON'ISPICE}

MORDA (1733-1799)

Le nom de Borda doit une partie de sa célébrité au fait qu'il a été porté pendant soixante-treize ans par le vaisscau-écol des officiers de la Marine militaire française. Ce nom y fut le symbole de la triple valeur scientifique, technique et militaire; mais il n'est pas resté pour cela l'apanage exclusit de lat Marine : il appartient à la Science sous ba forme la plus génétale.

Ce fut une curieuse carric̀re que celle du chevalier Jean Charles de Borda, né à Dax le 4 mai 1733, dans une fanille de seize enfants, et qui, destiné à devenir magistrat, fut successivement officier du génie, officier de chevau-légers, capitaine de vaisseau, directeur de l'Ecole des Ingenieurs de la Marine, et membre de l'Institut, dont, age de vingt ans seulement, il était déji membre correspondant.

Fréoccupé, dès 1756 , cle la dynamique des fluides, comme en témoigne son mémoirc sur la résistance qute l'air oppose aux projectiles dartillerie - travail d'une importance preponderante dans lhistoire de la balistique - il s'adonna a l'hy drodynamique en, etudiant la resistance de leaul sur les navires, les hlets dreat dans les pompes, les econlements thiles par divers orifees on ajutages a ce sujet, il mit en evi cence lo pertes de charge par clargissentent, buthe cantures cepuls lors sous lo chare par

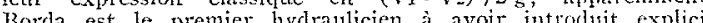

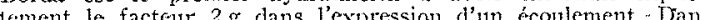
tement le facteur $2 \mathrm{~g}$ dans lexpression d'un econlenent. "Dan. ur: menoire de 1767 a Acadenie des Sciences, il avait de hini les conditions requises d'un réceptetr tel 'It'tune rout hyclratlique ponr donner lun bon rendement : " L'eau doit $y$ entrer sans choc et en sortir sans vitesse $》 ;$; il y clonnai ainsi la theorie $d$ " tne espece particuliere de roues hor zontales a palettes cotrbes 》, qui compte parmi les plus reFourtialey

Fourneyron. l'immense portée de ses travaux : on lui doit notamment célèbre cercle répétiteur à réflexion, la « double pesée »prototype des méthodes de zéro - l'étude des montres de marine en vile de la détermination des longitudes, des tables de logarithmes is 7 décimales des lignes trigonométriques dans le système décimal (qu'il calcula et fit imprimer à ses frais) et, chose très importante, les travalux qui ellrent pour résultat la création du système métrique. Sa générosité proverbiale, son désintéressement absolu et sa modestie excessive sont parmi les traits saillants du carac tère de ce savant, dont on a pu dire que « ce magnifique exemplaire d'humanité " poursuivit toute sa vie un idéal unique : "Savoir les choses pour servir les hommes. 》

Borda mourut ì Paris le 19 février 1799
BORDA (1733-1799).

Part of Borda's fame is dite to the fact that the French Naval Officer's Traiting Ship bore his name for 73 year. His name zuas it symbol of scientific, technical and naval merit but it was not the exclusive property of the Navy for Borda belongea to science in its most general form.

Jcan-Charles Borda, who was born into a family of sixteen children at Dax on Moy th 1733, had a strange career, for he zoho eventrally became a magistrate wisa first of all an officer in the Corps of Engineers, then an officer in the light cavalry, a captain in the Navy, director of the school of naval

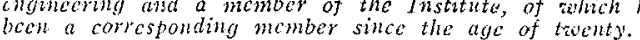

From 1756 onvards he was greatly interested in fluid dynamics as is evidenced by his paper on the resistance of air to projectiles fired from gunts, a paper which avis to be of great importance wi. the history of ballistics. He took up hydrody. mamics and investigated the resistance of avate to the motion of ships, stram hines in pumps and flow throngh varions arices and ontlet thbes. In connection woith this he drew in cross section. Sinch losses havo ever since beon havease in cross section. Such losses have ever since been knower. a Borda losses after Borda

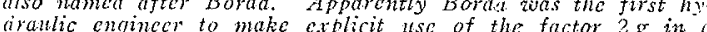
flow equation Sciences in 1767 , he defined the conditions and Acadcmy of

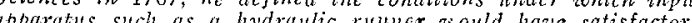
apparatis suth as a hydrollic rminter ziould have satisfactory cfficiency. He said The water should cuter arthout shoc "and leave without speed." He thus ontlined the theory of "a special type of horizontal whed reith curved blades," Burdin and Fourneyron turbine.

The immense scope of Borda's work won him universal scien. tific recolsmition. Among the things due to Borda are the famous repeating reflecting circle, the double weighing method a precursor of the zero mothods), investigations relating to decimal triganometrical tubles (wohich he computed an place

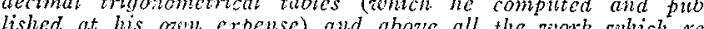

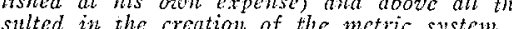

His proverbial generosity, his absolute disinterestedness and his excessize modesty are among the outstanding features of the character of this scientist, of whom it has been said that "this magnificent example of humanity". kept one ideal in mind throughout his life : "To know things in order to

Borda dicd in Paris on February 19th 1799. 